\title{
LA-UR-20-24082
}

Approved for public release; distribution is unlimited.

Title: $\quad(\mathrm{U})$ Energy-Dependent Perturbations of Scattering Cross Sections Using the PERT Card in MCNP6.2

Author(s): $\quad$ Favorite, Jeffrey A.

Parsons, Donald Kent

Intended for: Report

Issued: 
Disclaimer:

Los Alamos National Laboratory, an affirmative action/equal opportunity employer, is operated by Triad National Security, LLC for the National Nuclear Security Administration of U.S. Department of Energy under contract 89233218CNA000001. By approving this article, the publisher recognizes that the U.S. Government retains nonexclusive, royalty-free license to publish or reproduce the published form of this contribution, or to allow others to do so, for U.S. Government purposes. Los Alamos National Laboratory requests that the publisher identify this article as work performed under the auspices of the U.S. Department of Energy. Los Alamos National Laboratory strongly supports academic freedom and a researcher's right to publish; as an institution, however, the Laboratory does not endorse the viewpoint of a publication or guarantee its technical correctness. 
Los Alamos

NATIONAL LABORATORY

memorandum

$X$-Computational Physics Division

Radiation Transport Applications Group

Group XCP-7, MS F663

Los Alamos, New Mexico 87545

505/667-1920
To/MS: Distribution

From/MS: Jeffrey A. Favorite / XCP-7, MS F663

D. Kent Parsons XCP-5, MS F663

Phone/Email: 7-7941 / fave@lanl.gov

Symbol: XCP-7:20-016(U) (LA-UR-20-?????)

Date: June 3, 2020

\section{SUBJECT: (U) Energy-Dependent Perturbations of Scattering Cross Sections Using the PERT Card in MCNP6.2}

\section{Introduction}

The PERT card is used for first- and second-order perturbations of material densities, isotope densities, and isotope cross sections in the MCNP6.2 Monte Carlo code. ${ }^{1}$ Using the PERT card for firstand second-order sensitivities is straightforward. ${ }^{2}$ Reference 2 only looked at density perturbations with no energy dependence. This report looks at the sensitivity of a response to scattering cross sections as a function of energy and finds that there is a bug in the PERT capability.

The SENSMG multigroup neutron sensitivity $\operatorname{code}^{3,4}$ was recently given the capability of computing sensitivities to user-specified reactions whose cross sections are available in a user-supplied NJOY output file. ${ }^{5}$ SENSMG uses the PARTISN multigroup discrete ordinates code ${ }^{6}$ for the transport. The NJOY-reaction capability is similar to that of SUSD3D (Refs. 7 and 8), which also uses PARTISN for the multigroup transport.

The PERT bug was identified by comparing MCNP6.2 outputs with SENSMG outputs.

The next section of this report describes the test problem. Section III presents the MCNP6.2 PERT bug and proposes a solution. Section IV is a summary and conclusions. The SENSMG and MCNP input files are listed in the appendix. 


\section{Test Problem}

The test problem used in this report is a one-dimensional sphere with two materials. The geometry is a simplified version of the BeRP ball reflected with polyethylene. ${ }^{9}$ The materials are defined in Table I and dimensions are shown there and in Figure 1. The $\alpha$-Pu of Table I is a simplification of the material specification given in Ref. 9 in which the impurities were replaced with natural gallium.

Table I. Materials and Geometry of the Test Problem.

\begin{tabular}{|c|c|c|c|c|}
\hline Index & Material & Composition (Weight Fraction) & $\begin{array}{c}\text { Density } \\
\left(\mathrm{g} / \mathrm{cm}^{3}\right)\end{array}$ & $\begin{array}{c}\text { Outer } \\
\text { Radius (cm) }\end{array}$ \\
\hline 1 & $\alpha-\mathrm{Pu}$ & ${ }^{239} \mathrm{Pu} 9.38039 \mathrm{E}-01 ;{ }^{240} \mathrm{Pu} 5.94112 \mathrm{E}-02 ;$ & 19.6 & 3.794 \\
2 & Polyethylene & ${ }^{69} \mathrm{Ga} 1.51515 \mathrm{E}-03 ;{ }^{71} \mathrm{Ga} 1.03465 \mathrm{E}-03$ & 0.95 & 7.604 \\
\hline
\end{tabular}

This experiment measured neutron and gamma-ray leakage and subcritical multiplication in Ref. 9. Here we use the system's total neutron leakage.

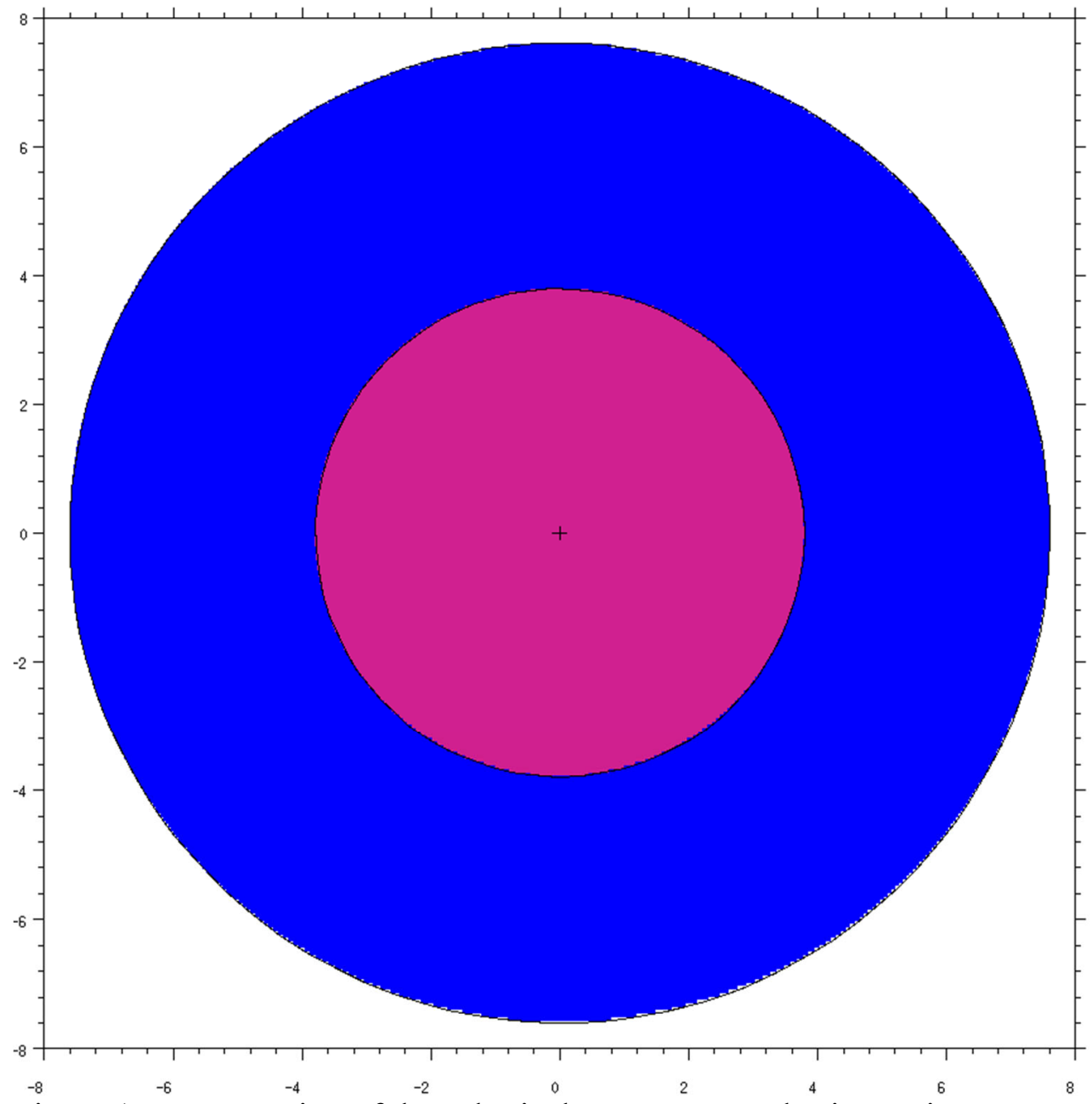

Figure 1. Cross-section of the spherical geometry. Scales in centimeters. 
The calculations used ENDF/B-VIII.0 cross sections. The MCNP6.2 calculations used ZAID extension 00c. PARTISN calculations used LIBNAME $=m t 80$. Because the multigroup cross sections do not include $S(\alpha, \beta)$ scattering, the Monte Carlo calculations were also done without $S(\alpha, \beta)$ scattering.

PARTISN version 8.31.37 was used with $S_{256}$ quadrature, $P_{3}$ scattering, and a convergence criterion (PARTISN's epsi) of 1E-6. These parameters were set on the SENSMG input line. The fine mesh spacing was $0.005 \mathrm{~cm}$ for both regions. The calculations used 36 processors.

PARTISN calculations used 250 energy groups. The 250-energy-group structure from the NDI was used for the MCNP source and tallies, including PERT cards.

Table II compares the MCNP and PARTISN results for the total leakage. The difference of $-4.6 \%$ (with respect to MCNP) is due to the lack of self-shielding in the multigroup cross sections. (Thomas Saller [CCS-2] confirmed this with a 261-group library based on ENDF/B-VII.1. ${ }^{10}$ )

Table II. Calculated Leakage.

\begin{tabular}{|c|c|c|}
\hline Code & Energy Treatment & Leakage (neutrons/s) \\
\hline MCNP6.2 & Continuous & $1.91962 \mathrm{E}+06 \pm 0.03 \%$ \\
PARTISN & Multigroup & $1.8303897 \mathrm{E}+06$ \\
\hline
\end{tabular}

\section{MCNP PERT Bug}

\section{III.A. Problem}

Figure 2 compares the sensitivity of the neutron leakage to the $\mathrm{Pu}-239$ elastic scattering cross section computed using MCNP6.2 (with PERT cards) and SENSMG. Figure 3 is the same for the Pu-239 inelastic scattering cross section, which is the sum of MF 6, MT 51 through 91. For SENSMG, "sum" means the sum of the Legendre scattering moments. Also, for each energy group, the sensitivity is the sum of outgoing channels.

There is a large mismatch, including a negative peak at $5 \mathrm{E}-08 \mathrm{MeV}$ for the MCNP calculations. 


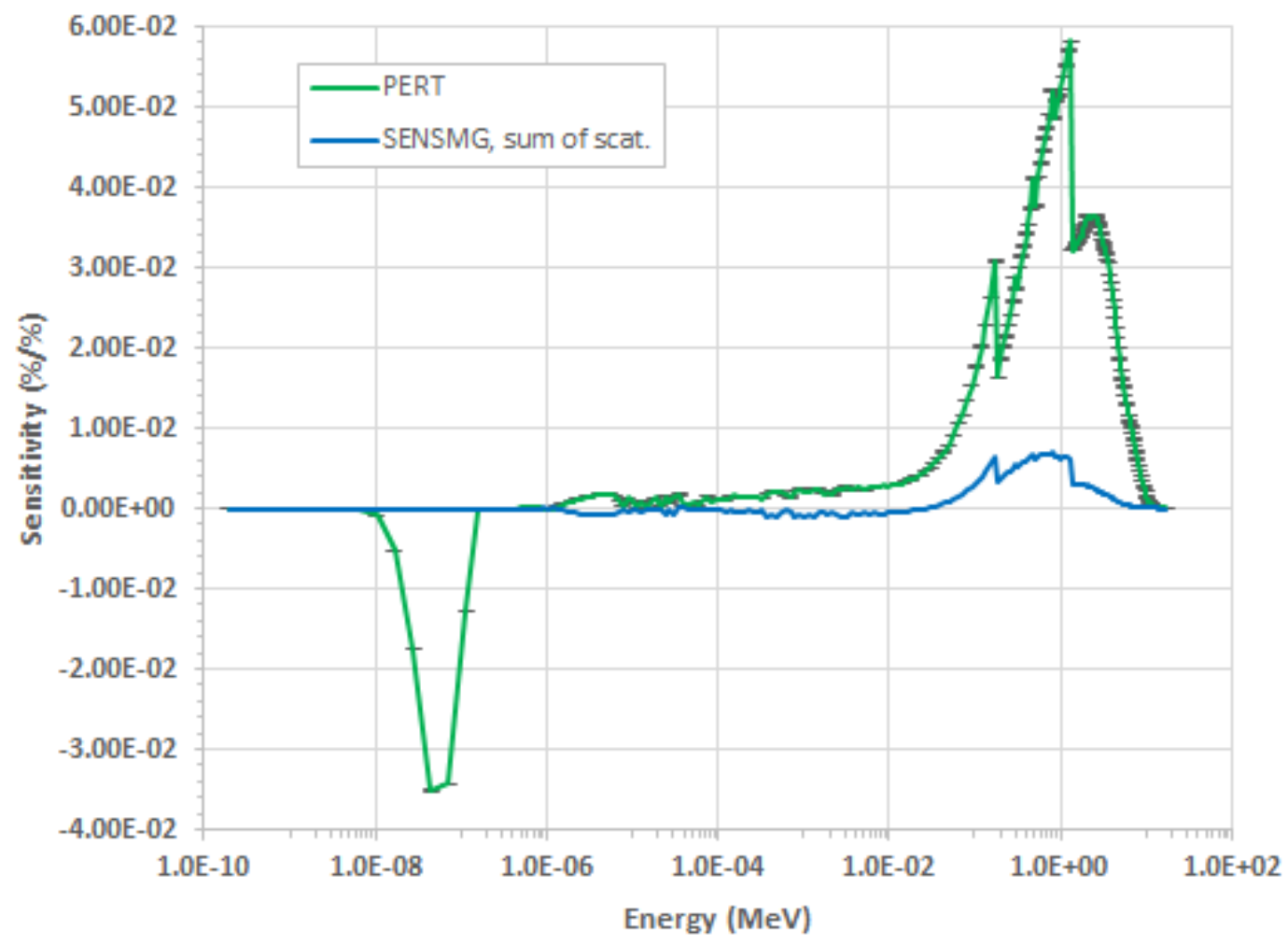

Figure 2. Sensitivity of the total leakage to Pu-239 elastic scattering. The PERT capability has a bug.

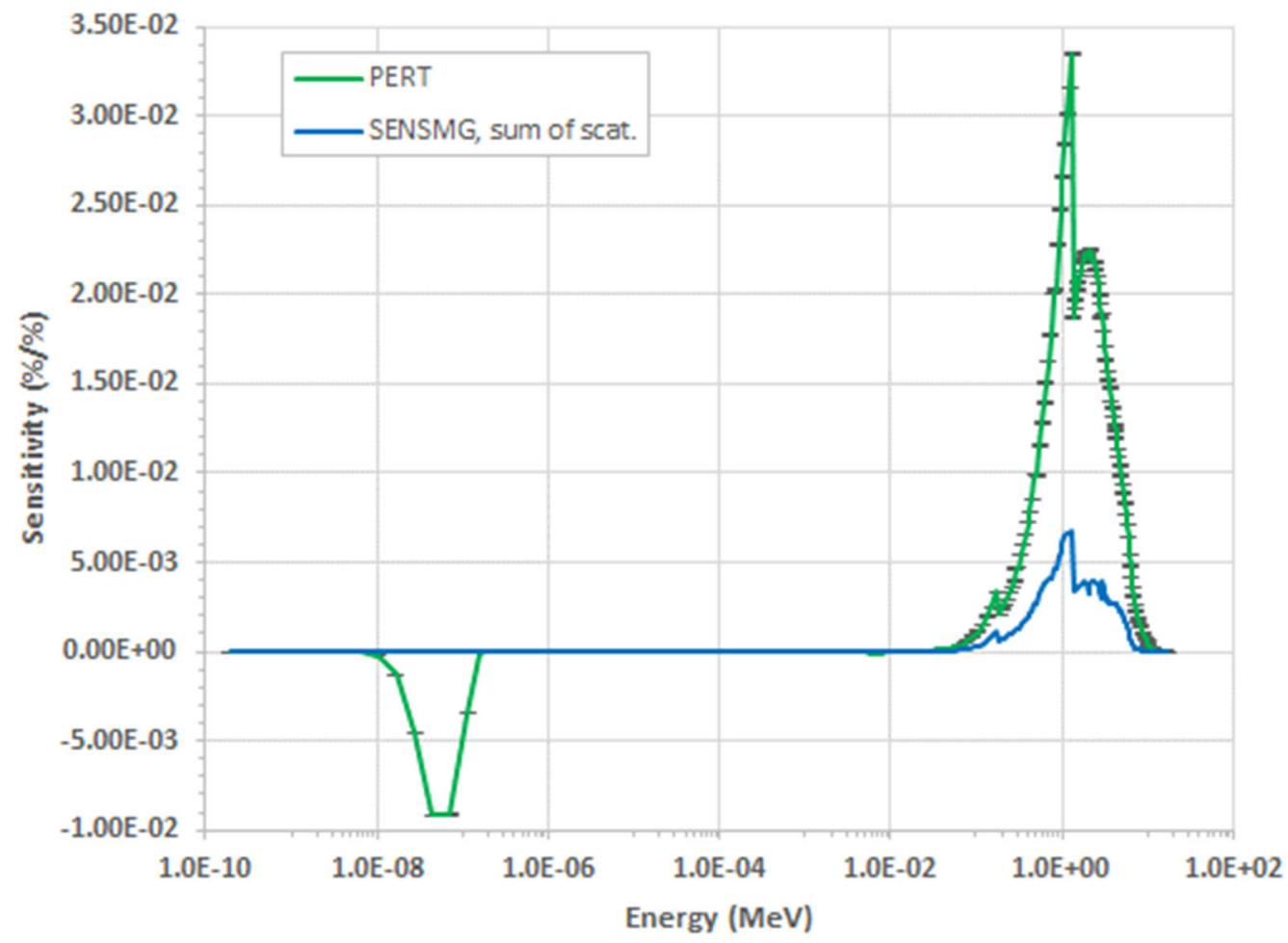

Figure 3. Sensitivity of the total leakage to Pu-239 inelastic scattering. The PERT capability has a bug. 


\section{III.B. Diagnosis and Solution}

Variable eg 0 is defined in tskcom as the "Energy of the particle before last collision". It is used in subroutine pert_difop_dtrack to help determine if the particle energy is within the boundaries set on the PERT card. The current particle energy is also used.

The problem is that eg 0 is not reset when a particle terminates. When a particle comes from the source or the bank, eg 0 still has the value that it had in the last collision. When the particle comes from the source, there is no problem in pert_difop_dtrack because iexp ("IEX from previous collision" defined in $\mathrm{pb}$ lcom) is 0 . However, when a particle is banked due to a collision, it comes out with a nonzero iexp, and eg 0 is used. But eg 0 has a value corresponding to the last thing that happened in the code, which likely has nothing to do with the particle that came from the bank.

Figure 4(a) is a snippet from an event log showing a neutron bouncing around in the plutonium (cell 1) and polyethylene (cell 2) before terminating by escape. Then a neutron comes from the bank into the plutonium (cell 1). This snippet also has eg 0 printed at the end of subroutine eventp. The neutron from the bank has the same eg 0 that the previous neutron had when it escaped. Perturbations using this value of eg 0 score in the wrong bin.

We think that when a neutron comes from the bank, it should have eg 0 equal to the value it had when the neutron went into the bank. Thus eg 0 should be a banked variable.

We modified MCNP to use eg 0 as spare (1) (thank you whoever put in those spares all those centuries ago!). Everywhere we found "eg0 =" (charged_particle_history.F90, chg_pl_lcaopt.F90, electr.F90, electron_history.F90, history_neutral_high.F90, hstory.F90, neu_pl_lcaopt.F90,single_event_electrons.F90, and xs_calc.F90), we added the line

$\mathrm{pb} 1 \%$ r\%spare $(1)=$ eg0

We don't know if this is the right thing to do in all cases.

In subroutine unbank_particle, after "call gpbl_unbank", we added eg0 0 pbl\%rospare $(1)$

For good measure, in subroutine startp, after "enddo SAMPLE_SRC", we initialized eg0 with eg $0=0 . \mathrm{d} 0$ $\mathrm{pbl} \div \mathrm{r} \% \mathrm{spare}(1)=\operatorname{eg} 0$

We don't know if that's the right place to do it. Maybe it should be done in subroutine neutron_photon_history where pbloi\%iexp is set to 0 .

Variable eg 0 is used a lot in charged particle tracking and we don't know how this proposed solution affects that. However, none of the regular regression problems had any changes.

Figure 4(b) is a snippet from the same point in the event log as Figure 4(a). It shows that the neutron from the bank has the correct value of eg 0 , that of the neutron when it went into the bank.

Figure 5 and Figure 6 show that PERT and SENSMG sensitivities of Pu-239 elastic and inelastic scattering agree when the PERT bug is fixed as discussed above. 


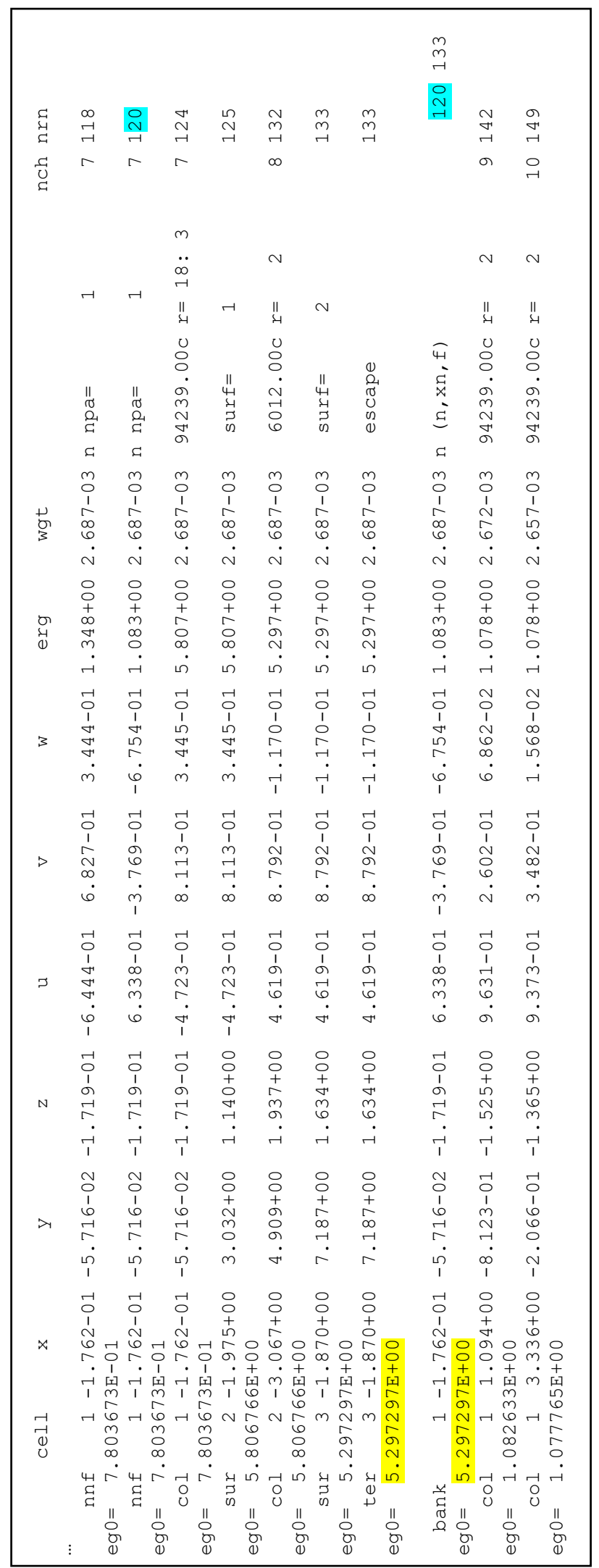

(a)

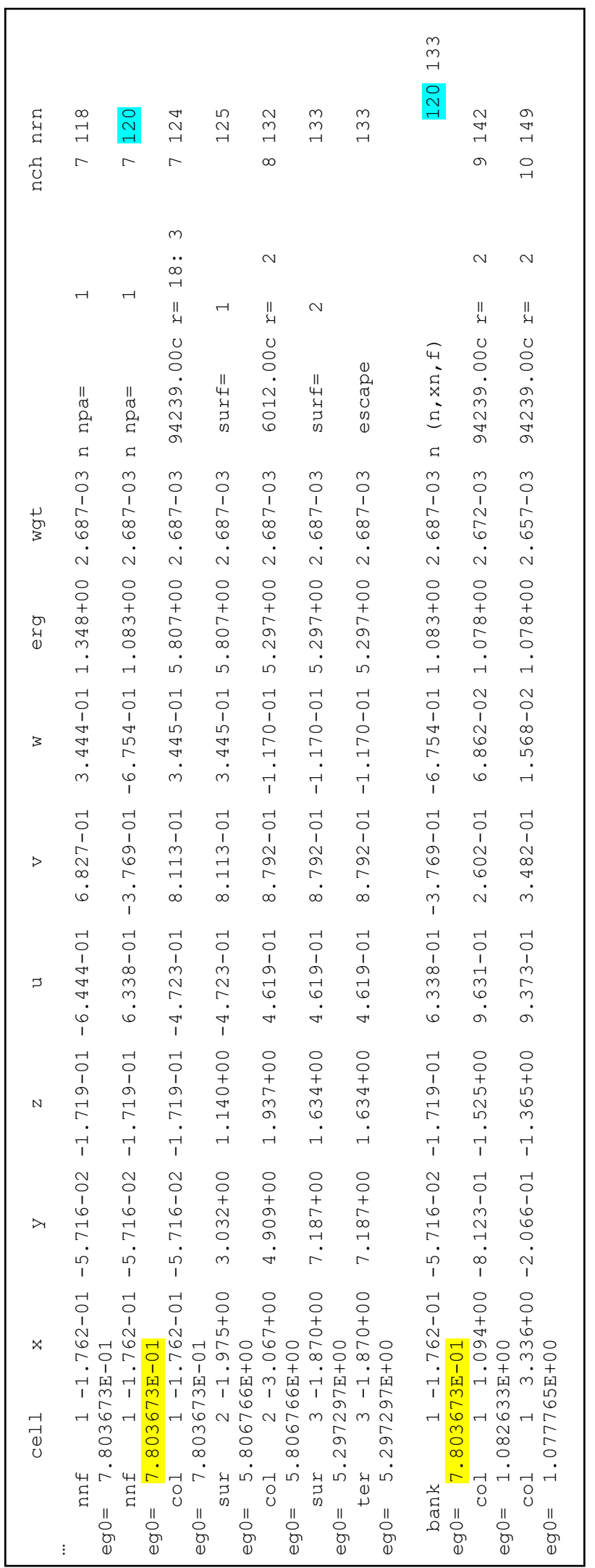

(b)

Figure 4. Event log snippets. (a) From unmodified MCNP6.2 showing eg0 is the last value from an unrelated history. (b) From modified MCNP6.2 showing eg 0 has the correct value. 


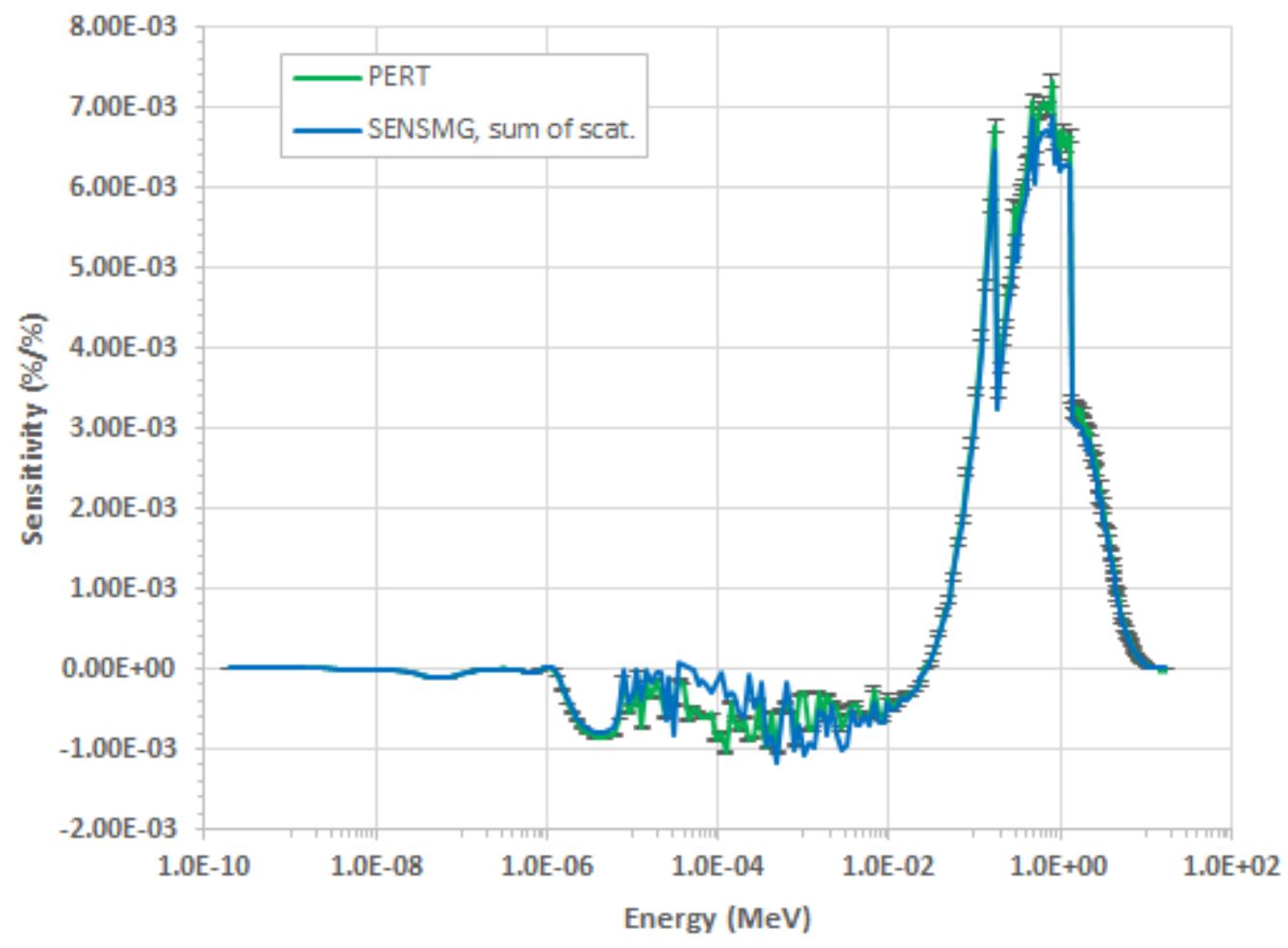

Figure 5. Sensitivity of the total leakage to Pu-239 elastic scattering when the PERT bug is fixed.

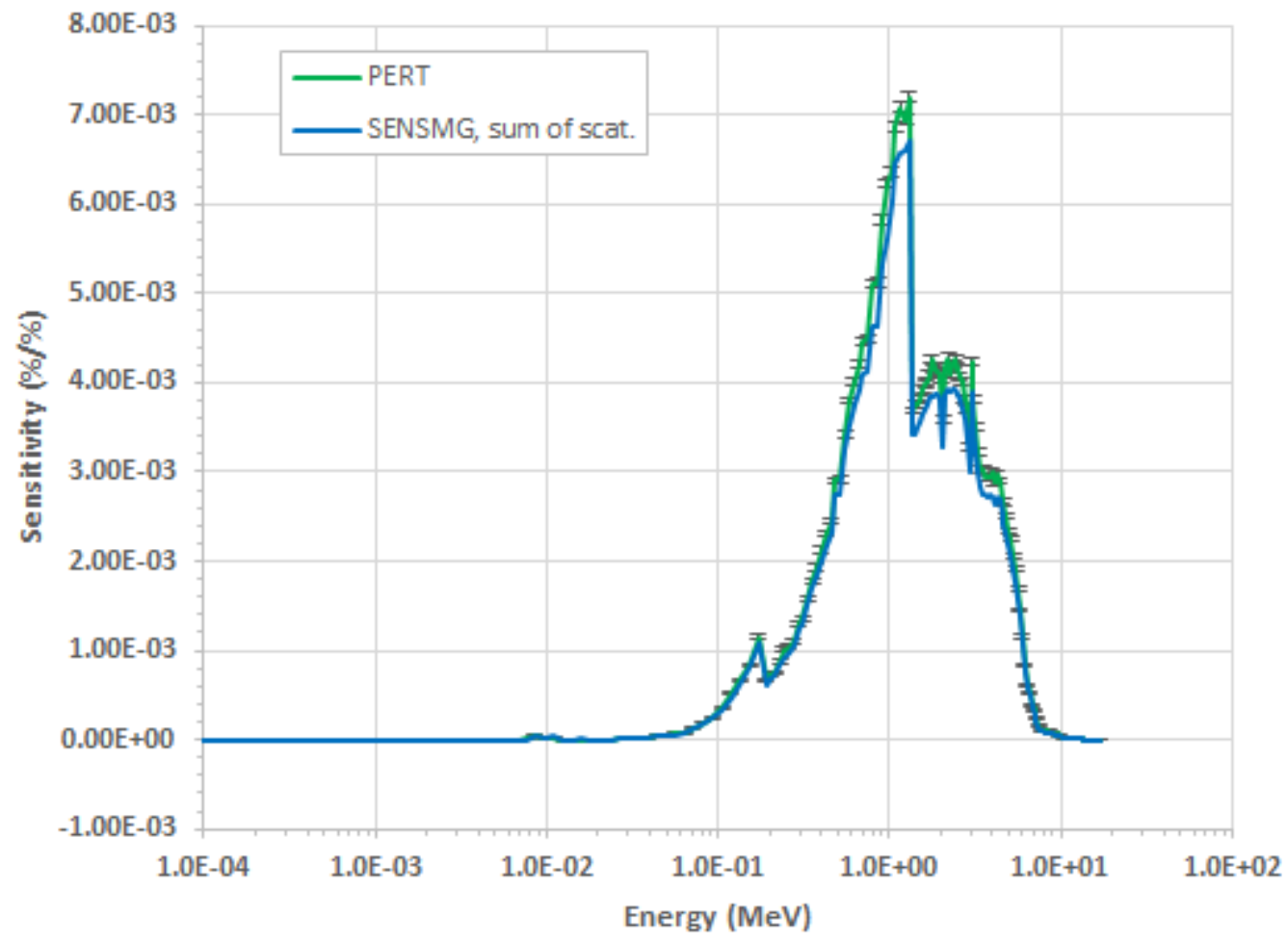

Figure 6. Sensitivity of the total leakage to Pu-239 inelastic scattering when the PERT bug is fixed. 


\section{Summary and Future Work}

There is a bug in the MCNP6.2 PERT capability that affects energy-dependent perturbations. It is not known if this bug affects energy-dependent tallies. A simple fix is provided.

The SENSMG and MCNP input files are listed in the appendix.

\section{References}

1. Christopher J Werner, ed., “MCNP ${ }^{\circledR}$ User’s Manual, Code Version 6.2," Los Alamos National Laboratory report LA-UR-17-29981, Rev. 0 (Oct. 27, 2017).

2. Jeffrey Favorite, "Using the MCNP Taylor Series Perturbation Feature (Efficiently) for Shielding Problems," Proceedings of the $13^{\text {th }}$ International Conference on Radiation Shielding (ICRS-13) \& $19^{\text {th }}$ Topical Meeting of the Radiation Protection and Shielding Division of the American Nuclear Society (RPSD-2016), CD-ROM <Oral/T6/T6_S7/000197_FP.pdf>, Paris, France, October 3-6 (2016); European Physics Journal-Web of Conferences, 153, 06030 (2017); https://doi.org/10.1051/epjconf/201715306030.

3. Jeffrey A. Favorite, "SENSMG: First-Order Sensitivities of Neutron Reaction Rates, Reaction-Rate Ratios, Leakage, $k_{e f f}$, and $\alpha$ Using PARTISN," Nuclear Science and Engineering, 192, 1, 80-114 (2018); https://doi.org/10.1080/00295639.2018.1471296.

4. Jeffrey A. Favorite, “(U) SENSMG: First-Order Sensitivities of Neutron Reaction Rates, ReactionRate Ratios, Leakage, $k_{e f f}, \alpha$, and Subcritical Multiplication Using PARTISN," Rev. 1, Los Alamos National Laboratory report LA-UR-19-26249 (September 19, 2019).

5. A. C. Kahler, ed., "The NJOY Nuclear Data Processing System, Version 2012," Los Alamos National Laboratory report LA-UR-12-27079 (Dec. 20, 2012).

6. R. E. Alcouffe, R. S. Baker, J. A. Dahl, E. J. Davis, T. G. Saller, S. A. Turner, R. C. Ward, and R. J. Zerr, "PARTISN: A Time-Dependent, Parallel Neutral Particle Transport Code System," Version 8.31, Los Alamos National Laboratory report LA-UR-17-29704 (Revised September 2019).

7. Ivan Kodeli, "SUSD3D Computer Code as Part of the XSUN-2017 Windows Interface Environment for Deterministic Radiation Transport and Cross-Section Sensitivity-Uncertainty Analysis," Nucl. Sci. Eng., 138, 1, 45-66 (2001); https://doi.org/10.13182/NSE00-43.

8. Ivan A. Kodeli and Slavko Slavič, "Multidimensional Deterministic Nuclear Data Sensitivity and Uncertainty Code System: Method and Application," Sci. Technol. Nucl. Install., 2017, 16 pages (2017); https://doi.org/10.1155/2017/1264736.

9. J. Mattingly, "Polyethylene-Reflected Plutonium Metal Sphere: Subcritical Neutron and Gamma Measurements," SAND2009-5804, Sandia National Laboratory (2009); https://doi.org/10.2172/974870.

10. Thomas Saller, email to Jeffrey A. Favorite, March 10, 2020. 


\section{JAF:jaf}

Distribution:

J. T. Goorley, XCP-7, MS A143, jgoorley@lanl.gov

P. Talou, XCP-5, MS F644, talou@lanl.gov

S. D. Ramsey, XTD-NTA, MS T082, ramsey@lanl.gov

H. G. Highes, XCP-3, MS A143, hgh@lanl.gov

J. A. Kulesza, XCP-3, MS A143, jkulesza@lanl.gov

M. E. Rising, XCP-3, MS F663, mrising@lanl.gov

J. E. Sweezy, XCP-3, MS A143, jsweezy@lanl.gov

T. J. Trahan, XCP-3, MS F663, tjtrahanelanl.gov

A. R. Clark, XCP-5, MS P365, arclark@lanl.gov J. L. Conlin, XCP-5, MS F663, jlconlinelanl.gov

W. Haeck, XCP-5, MS P365, wimelanl.gov

D. K. Parsons, XCP-5, MS F663, dkp@lanl.gov

J. A. Favorite, XCP-7, MS F663, faveelanl.gov

National Security Research Center, nsrc-cataloging@lanl.gov

XCP-5 File

XCP-7 File 


\section{APPENDIX}

\section{INPUT FILES FOR THE TEST PROBLEM}

\section{SENSMG Input File}

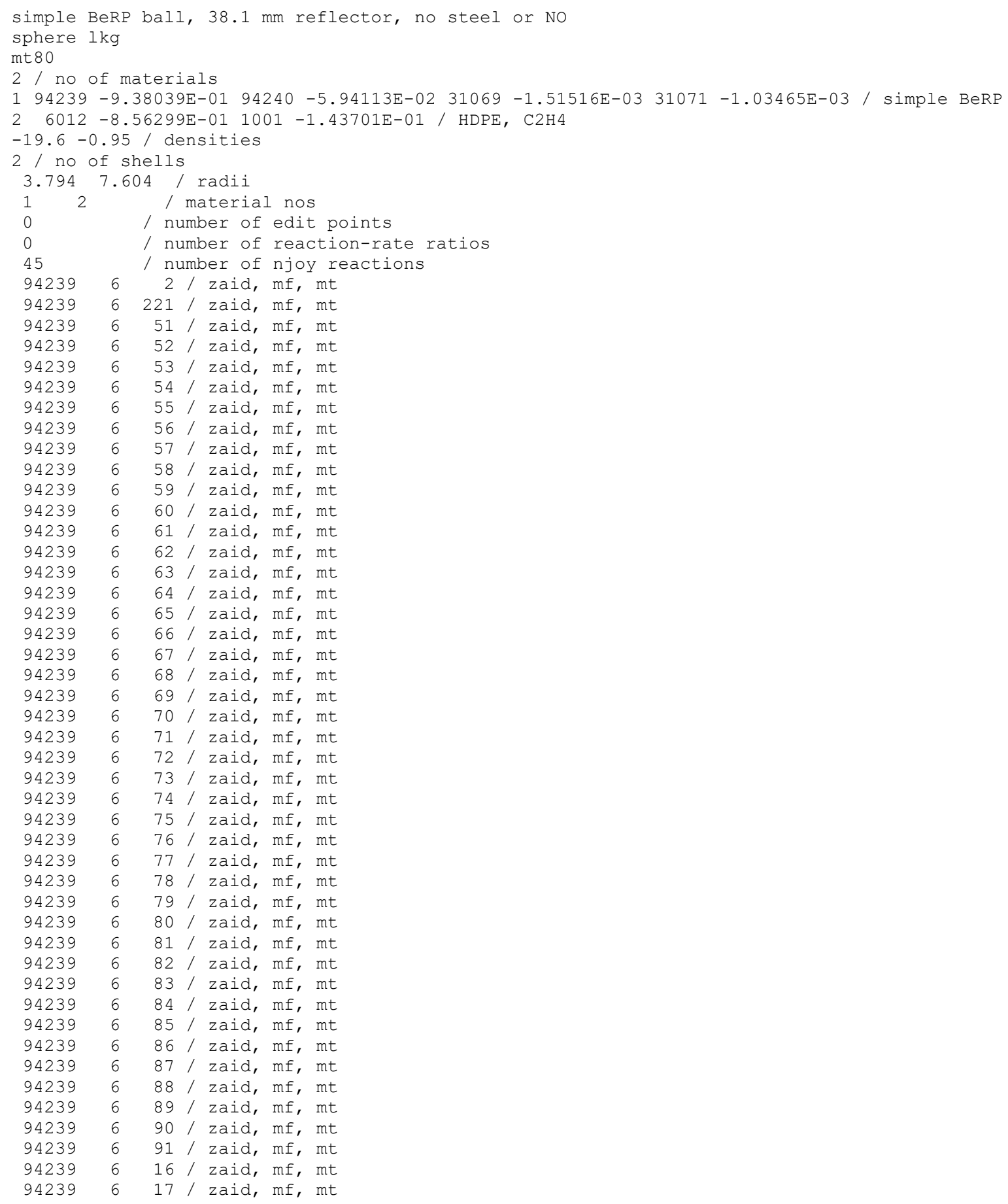


$5.71501 \mathrm{E}-06$

$6.47595 \mathrm{E}-06$

7. $33822 \mathrm{E}-06$

0.00000832

9. $42245 \mathrm{E}-06$

0.000010677

$1.20987 \mathrm{E}-05$

$1.37096 \mathrm{E}-05$

0.000015535

$1.76035 \mathrm{E}-05$

$1.99473 \mathrm{E}-05$

0.0000226

$2.56129 \mathrm{E}-05$

$2.90232 \mathrm{E}-05$

3. $28876 \mathrm{E}-05$

$3.72665 \mathrm{E}-05$

$4.22285 \mathrm{E}-05$

$4.78512 \mathrm{E}-05$

$5.42225 \mathrm{E}-05$

0.0000614

0.000069623

$7.88932 \mathrm{E}-05$

8.93978E-05

0.000101301

0.000114789

0.000130073

0.000147392

0.000167

0.000189255

0.000214454

0.000243008

0.000275364

0.000312029

0.000353575

0.000400653

0.000454

0.000514449

0.000582947

0.000660565

0.000748518

0.000848182

0.000961117

0.00108909

0.001235

0.00139842

0.00158461

0.0017956

0.00203468

0.0023056

0.00261259

0.00296045

0.00335

0.00380129

0.00430743

0.00488095

0.00553084

0.00626727

0.00710174

0.00804733

0.00912

0.010333

0.0117088

0.0132678

0.0150344

0.0170362

0.0193045

0.0218749

0.0248

0.0280879

0.0318278

0.0360656

0.0408677

0.0463092

0.0524752
$1.18813 \mathrm{E}-06$

$1.43316 \mathrm{E}-06$

$1.72874 \mathrm{E}-06$

$2.0956 \mathrm{E}-06$

2. $5049 \mathrm{E}-06$

$3.03391 \mathrm{E}-06$

$3.65988 \mathrm{E}-06$

4. $41439 \mathrm{E}-06$

5. $3248 \mathrm{E}-06$

$6.42308 \mathrm{E}-06$

7. $74732 \mathrm{E}-06$

$9.33351 \mathrm{E}-06$

$1.12846 \mathrm{E}-05$

$1.35973 \mathrm{E}-05$

1. $64015 \mathrm{E}-05$

1. $97838 \mathrm{E}-05$

$2.3864 \mathrm{E}-05$

$2.87855 \mathrm{E}-05$

3. $47216 \mathrm{E}-05$

$4.16302 \mathrm{E}-05$

$5.07709 \mathrm{E}-05$

$6.09377 \mathrm{E}-05$

$7.35051 \mathrm{E}-05$

$8.86631 \mathrm{E}-05$

0.000106947

0.000129002

0.000155605

0.000187526

0.000226567

0.000273087

0.000329399

0.000397326

0.00047927

0.000578087

0.000697295

0.000841088

0.001014501

0.001223689

0.001475991

0.001780321

0.002147384

0.002590129

0.003124136

0.003792233

0.004520833

0.005481524

0.006611632

0.007974195

0.009617794

0.01159959

0.013989372

0.016667335

0.020550878

0.024537572

0.029589716

0.035681932

0.043026848

0.051879886

0.062553216

0.075502497

0.090836521

0.109601298

0.132112518

0.159232942

0.191895871

0.231229206

0.278599548

0.3370903

0.402726759

0.486749533

0.585990022

0.705296028

0.848633255

1.020747909 


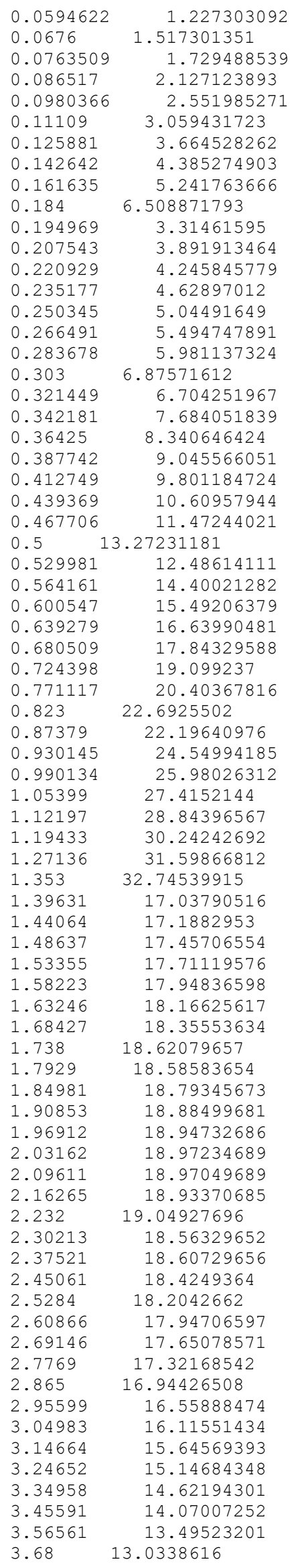




$$
\begin{aligned}
& 3.79557 \quad 12.15952082 \\
& 3.91606 \quad 11.66940039 \\
& 4.04037 \quad 11.03664982 \\
& 4.16862 \quad 10.39821926 \\
& 4.30095 \quad 9.758989686 \\
& 4.43747 \quad 9.120133118 \\
& 4.57833 \quad 8.487907555 \\
& 4.72367 \quad 7.864778 \\
& \begin{array}{ll}
4.87361 & 7.253074456
\end{array} \\
& 5.02832 \quad 6.658405926 \\
& 5.18793 \quad 6.081763413 \\
& 5.35261 \quad 5.52743692 \\
& 5.52252 \quad 4.997248448 \\
& 5.69783 \quad 4.493469999 \\
& 5.8787 \quad 4.017508576 \\
& 6.07 \quad 3.654075252 \\
& 6.25784 \quad 3.072292735 \\
& 6.45649 \quad 2.770539466 \\
& 6.66144 \quad 2.416887151 \\
& 6.87289 \quad 2.094315864 \\
& \begin{array}{ll}
7.09106 & 1.802374604
\end{array} \\
& 7.31616 \quad 1.540009371 \\
& 7.5484 \quad 1.306048162 \\
& \begin{array}{ll}
7.79 & 1.107380986
\end{array} \\
& 8.03523 \quad 0.90956431 \\
& 8.29029 \quad 0.759993976 \\
& 8.55345 \quad 0.624039055 \\
& 8.82497 \quad 0.507918452 \\
& \begin{array}{ll}
9.1051 & 0.409636365
\end{array} \\
& 9.39413 \quad 0.327294691 \\
& 9.69233 \quad 0.258958231 \\
& \begin{array}{ll}
10 & 0.202841981
\end{array} \\
& 10.25 \quad 0.127557614 \\
& 10.5 \quad 0.10135669 \\
& 10.75 \quad 0.080455962 \\
& 11 \quad 0.063802737 \\
& 11.25 \quad 0.050548745 \\
& 11.5 \quad 0.040011516 \\
& 11.75 \quad 0.031642908 \\
& 12 \quad 0.025003262 \\
& 12.25 \quad 0.019740478 \\
& 12.5 \quad 0.015572924 \\
& 12.75 \quad 0.012275671 \\
& 130.009669236 \\
& 13.25 \quad 0.007610635 \\
& 13.5 \quad 0.00598605 \\
& 13.75 \quad 0.004704995 \\
& 14 \quad 0.003695606 \\
& 14.25 \quad 0.002900866 \\
& \begin{array}{ll}
14.5 & 0.002275583
\end{array} \\
& 14.75 \quad 0.001783972 \\
& 15 \quad 0.00139772 \\
& 15.25 \quad 0.001094451 \\
& \begin{array}{ll}
15.5 & 0.00085649
\end{array} \\
& \begin{array}{ll}
15.75 & 0.000669892
\end{array} \\
& \begin{array}{ll}
16 & 0.000523659
\end{array} \\
& 16.25 \quad 0.000409129 \\
& \begin{array}{ll}
16.5 & 0.000319481
\end{array} \\
& 16.75 \quad 0.000249349
\end{aligned}
$$

sbo02 0.0.1.249r

$\mathrm{f} 1: \mathrm{n} \quad 2$

pert001:n cell=1 mat=2 rho=9.598577845E-02 $r \times n=2$ erg $=0.00000 \mathrm{E}+001.39000 \mathrm{E}-10$ method $=2$ pert002:n cell=1 mat=2 rho=9.598577845E-02 rxn=2 erg $=1.39000 \mathrm{E}-102.43741 \mathrm{E}-10$ method=2 pert003:n cell=1 mat=2 rho=9.598577845E-02 rxn=2 erg $=2.43741 \mathrm{E}-10 \quad 4.01861 \mathrm{E}-10$ method $=2$ pert004:n cell=1 mat=2 rho=9.598577845E-02 rxn=2 erg $=4.01861 \mathrm{E}-10 \quad 6.62557 \mathrm{E}-10$ method $=2$

pert005:n cell=1 mat=2 rho=9.598577845E-02 $r \times n=2$ erg $=6.62557 \mathrm{E}-101.09237 \mathrm{E}-09$ method $=2$ pert006: $\mathrm{n}$ cell=1 mat=2 $\mathrm{rho}=9.598577845 \mathrm{E}-02 \mathrm{rxn}=2$ erg=1.09237E-09 1.80102E-09 method=2 
pert007:n cell=1 mat=2 $r h o=9.598577845 \mathrm{E}-02 \mathrm{rxn}=2$ erg $=1.80102 \mathrm{E}-092.96937 \mathrm{E}-09$ method $=2$

pert008:n cell=1 mat=2 rho=9.598577845E-02 rxn=2 erg $=2.96937 \mathrm{E}-09 \quad 4.89567 \mathrm{E}-09$ method=2

pert009: $\mathrm{n}$ cell=1 mat=2 rho=9.598577845E-02 rxn=2 erg $=4.89567 \mathrm{E}-098.07159 \mathrm{E}-09$ method $=2$

pert010:n cell=1 mat=2 rho=9.598577845E-02 $r \times n=2$ erg $=8.07159 \mathrm{E}-091.25015 \mathrm{E}-08$ method $=2$

pert011:n cell=1 mat=2 rho=9.598577845E-02 $r \times n=2$ erg $=1.25015 \mathrm{E}-082.06115 \mathrm{E}-08$ method $=2$

pert012: n cell=1 mat=2 rho=9.598577845E-02 $r \times n=2$ erg $=2.06115 \mathrm{E}-08 \quad 3.39827 \mathrm{E}-08$ method $=2$

pert013:n cell=1 mat=2 rho=9.598577845E-02 $r \times n=2$ erg $=3.39827 \mathrm{E}-08 \quad 5.60280 \mathrm{E}-08$ method $=2$

pert014: $\mathrm{n}$ cell=1 mat=2 rho=9.598577845E-02 rxn=2 erg $=5.60280 \mathrm{E}-08$ 9.23745E-08 method $=2$

pert015: n cell=1 mat=2 rho=9.598577845E-02 $r \times n=2$ erg $=9.23745 \mathrm{E}-08 \quad 1.52000 \mathrm{E}-07$ method $=2$

pert016:n cell=1 mat=2 rho=9.598577845E-02 $r x n=2$ erg $=1.52000 \mathrm{E}-07$ 1.72578E-07 method=2

pert017: $\mathrm{n}$ cell=1 mat=2 rho=9.598577845E-02 rxn=2 erg $=1.72578 \mathrm{E}-07 \quad 1.95557 \mathrm{E}-07$ method $=2$

pert018: $\mathrm{n}$ cell=1 mat=2 rho=9.598577845E-02 rxn=2 erg $=1.95557 \mathrm{E}-07 \quad 2.21595 \mathrm{E}-07$ method $=2$

pert019:n cell=1 mat=2 rho=9.598577845E-02 rxn=2 erg $=2.21595 \mathrm{E}-07 \quad 2.51100 \mathrm{E}-07$ method=2

pert020:n cell=1 mat=2 rho=9.598577845E-02 rxn=2 erg $=2.51100 \mathrm{E}-07 \quad 2.84533 \mathrm{E}-07$ method $=2$

pert021:n celle1 mat=2 rho=9.598577845E-02 rxn=2 erg $=2.84533 \mathrm{E}-07 \quad 3.22419 \mathrm{E}-07$ method=2

pert022: n cell=1 mat=2 rho=9.598577845E-02 rxn=2 erg $=3.22419 \mathrm{E}-07 \quad 3.65348 \mathrm{E}-07$ method $=2$

pert023:n cell=1 mat=2 rho=9.598577845E-02 rxn=2 erg $=3.65348 \mathrm{E}-07 \quad 4.14000 \mathrm{E}-07$ method $=2$

pert024:n cell=1 mat=2 rho=9.598577845E-02 rxn=2 erg $=4.14000 \mathrm{E}-07 \quad 4.69116 \mathrm{E}-07$ method $=2$

pert025:n cell=1 mat=2 rho=9.598577845E-02 rxn=2 erg $=4.69116 \mathrm{E}-07 \quad 5.31579 \mathrm{E}-07$ method=2

pert026:n cell=1 mat=2 rho=9.598577845E-02 $r \times n=2$ erg $=5.31579 \mathrm{E}-07 \quad 6.02357 \mathrm{E}-07$ method $=2$

pert027:n cell=1 mat=2 rho=9.598577845E-02 rxn=2 erg $=6.02357 \mathrm{E}-07 \quad 6.82560 \mathrm{E}-07$ method $=2$

pert028:n cell=1 mat=2 rho=9.598577845E-02 rxn=2 erg $=6.82560 \mathrm{E}-07 \quad 7.73442 \mathrm{E}-07$ method $=2$

pert029:n cell=1 mat=2 rho=9.598577845E-02 rxn=2 erg $=7.73442 \mathrm{E}-078.76425 \mathrm{E}-07$ method=2

pert030:n cell=1 mat=2 rho=9.598577845E-02 rxn=2 erg $=8.76425 \mathrm{E}-07 \quad 9.93119 \mathrm{E}-07$ method $=2$

pert031:n cell=1 mat=2 rho=9.598577845E-02 rxn=2 erg $=9.93119 \mathrm{E}-07 \quad 1.13000 \mathrm{E}-06$ method $=2$

pert032: $\mathrm{n}$ cell=1 mat=2 rho=9.598577845E-02 rxn=2 erg $=1.13000 \mathrm{E}-061.27519 \mathrm{E}-06$ method $=2$

pert033: n cell=1 mat=2 rho=9.598577845E-02 rxn=2 erg $=1.27519 \mathrm{E}-061.44498 \mathrm{E}-06$ method=2

pert034:n cell=1 mat=2 rho=9.598577845E-02 $r \times n=2$ erg $=1.44498 \mathrm{E}-061.63738 \mathrm{E}-06$ method $=2$

pert035: $\mathrm{n}$ cell=1 mat=2 rho=9.598577845E-02 rxn=2 erg $=1.63738 \mathrm{E}-06 \quad 1.85539 \mathrm{E}-06$ method=2

pert036: $\mathrm{n}$ cell=1 mat=2 rho=9.598577845E-02 rxn=2 erg $=1.85539 \mathrm{E}-062.10243 \mathrm{E}-06$ method $=2$

pert037:n cell=1 mat=2 rho=9.598577845E-02 $r \times n=2$ erg $=2.10243 \mathrm{E}-062.38237 \mathrm{E}-06$ method=2

pert038:n cell=1 mat=2 rho=9.598577845E-02 $r \times n=2$ erg $=2.38237 \mathrm{E}-062.69958 \mathrm{E}-06$ method $=2$

pert039: $\mathrm{n}$ cell=1 mat=2 $\mathrm{rho}=9.598577845 \mathrm{E}-02 \mathrm{rxn}=2$ erg $=2.69958 \mathrm{E}-063.06000 \mathrm{E}-06$ method $=2$

pert $040: \mathrm{n}$ cell=1 mat=2 rho=9.598577845E-02 rxn=2 erg $=3.06000 \mathrm{E}-063.46633 \mathrm{E}-06$ method $=2$

pert041:n cell=1 mat=2 rho=9.598577845E-02 rxn=2 erg $=3.46633 \mathrm{E}-06 \quad 3.92786 \mathrm{E}-06$ method $=2$

pert042:n cell=1 mat=2 rho=9.598577845E-02 rxn=2 erg $=3.92786 \mathrm{E}-06$ 4.45085E-06 method=2

pert $043: \mathrm{n}$ cell=1 mat=2 rho=9.598577845E-02 rxn=2 erg $=4.45085 \mathrm{E}-065.04348 \mathrm{E}-06$ method $=2$ 
pert044:n cell=1 mat=2 rho=9.598577845E-02 rxn=2 erg $=5.04348 \mathrm{E}-065.71501 \mathrm{E}-06$ method $=2$

pert045:n cell=1 mat=2 rho=9.598577845E-02 rxn=2 erg $=5.71501 \mathrm{E}-06 \quad 6.47595 \mathrm{E}-06$ method=2

pert $046: \mathrm{n}$ cell=1 mat=2 rho=9.598577845E-02 rxn=2 erg $=6.47595 \mathrm{E}-067.33822 \mathrm{E}-06$ method $=2$

pert047:n cell=1 mat=2 rho=9.598577845E-02 $r \times n=2$ erg $=7.33822 \mathrm{E}-068.32000 \mathrm{E}-06$ method $=2$

pert048:n cell=1 mat=2 rho=9.598577845E-02 $r \times n=2$ erg $=8.32000 \mathrm{E}-069.42245 \mathrm{E}-06$ method $=2$

pert049: $\mathrm{n}$ cell=1 mat=2 $\mathrm{rho}=9.598577845 \mathrm{E}-02 \mathrm{rxn}=2$ erg $=9.42245 \mathrm{E}-061.06770 \mathrm{E}-05$ method $=2$

pert050:n cell=1 mat=2 rho=9.598577845E-02 rxn=2 erg=1.06770E-05 1.20987E-05 method=2

pert051:n cell=1 mat=2 rho=9.598577845E-02 rxn=2 erg $=1.20987 \mathrm{E}-051.37096 \mathrm{E}-05$ method $=2$

pert052: $\mathrm{n}$ cell=1 mat=2 $\mathrm{rho}=9.598577845 \mathrm{E}-02 \mathrm{rxn}=2$ erg $=1.37096 \mathrm{E}-051.55350 \mathrm{E}-05$ method $=2$

pert053:n cell=1 mat=2 rho=9.598577845E-02 $r x n=2$ erg $=1.55350 \mathrm{E}-051.76035 \mathrm{E}-05$ method=2

pert054: $\mathrm{n}$ cell=1 mat=2 rho=9.598577845E-02 rxn=2 erg $=1.76035 \mathrm{E}-051.99473 \mathrm{E}-05$ method $=2$

pert055: $\mathrm{n}$ cell=1 mat=2 $\mathrm{rho}=9.598577845 \mathrm{E}-02 \mathrm{rxn}=2$ erg $=1.99473 \mathrm{E}-052.26000 \mathrm{E}-05$ method=2

pert056:n cell=1 mat=2 rho=9.598577845E-02 rxn=2 erg $=2.26000 \mathrm{E}-052.56129 \mathrm{E}-05$ method=2

pert057:n cell=1 mat=2 rho=9.598577845E-02 rxn=2 erg $=2.56129 \mathrm{E}-052.90232 \mathrm{E}-05$ method $=2$

pert058: $\mathrm{n}$ celle1 mat=2 rho=9.598577845E-02 rxn=2 erg $=2.90232 \mathrm{E}-05 \quad 3.28876 \mathrm{E}-05$ method=2

pert059: $\mathrm{n}$ cell=1 mat=2 $r$ ho $=9.598577845 \mathrm{E}-02 \mathrm{r} \times \mathrm{n}=2$ erg $=3.28876 \mathrm{E}-05 \quad 3.72665 \mathrm{E}-05$ method $=2$

pert060:n cell=1 mat=2 rho=9.598577845E-02 rxn=2 erg $=3.72665 \mathrm{E}-05 \quad 4.22285 \mathrm{E}-05$ method $=2$

pert061:n cell=1 mat=2 rho=9.598577845E-02 rxn=2 erg $=4.22285 \mathrm{E}-054.78512 \mathrm{E}-05$ method $=2$

pert062: $\mathrm{n}$ cell=1 mat=2 rho=9.598577845E-02 rxn=2 erg $=4.78512 \mathrm{E}-055.42225 \mathrm{E}-05$ method $=2$

pert063:n cell=1 mat=2 rho=9.598577845E-02 rxn=2 erg $=5.42225 \mathrm{E}-05 \quad 6.14000 \mathrm{E}-05$ method $=2$

pert064:n cell=1 mat=2 rho=9.598577845E-02 rxn=2 erg $=6.14000 \mathrm{E}-056.96230 \mathrm{E}-05$ method $=2$

pert065: n cell=1 mat=2 rho $=9.598577845 \mathrm{E}-02 \mathrm{rxn}=2$ erg $=6.96230 \mathrm{E}-057.88932 \mathrm{E}-05$ method $=2$

pert066: $\mathrm{n}$ cell=1 mat=2 rho $=9.598577845 \mathrm{E}-02 \mathrm{rxn}=2$ erg $=7.88932 \mathrm{E}-058.93978 \mathrm{E}-05$ method=2

pert067:n cell=1 mat=2 rho=9.598577845E-02 $r \times n=2$ erg $=8.93978 \mathrm{E}-051.01301 \mathrm{E}-04$ method $=2$

pert068:n cell=1 mat=2 rho=9.598577845E-02 $r \times n=2$ erg $=1.01301 \mathrm{E}-041.14789 \mathrm{E}-04$ method $=2$

pert069:n cell=1 mat=2 rho=9.598577845E-02 rxn=2 erg $=1.14789 \mathrm{E}-041.30073 \mathrm{E}-04$ method $=2$

pert070:n cell=1 mat=2 rho=9.598577845E-02 rxn=2 erg $=1.30073 \mathrm{E}-041.47392 \mathrm{E}-04$ method=2

pert071:n cell=1 mat=2 rho=9.598577845E-02 $r \times n=2$ erg $=1.47392 \mathrm{E}-041.67000 \mathrm{E}-04$ method $=2$

pert072: $\mathrm{n}$ cell=1 mat=2 rho=9.598577845E-02 rxn=2 erg $=1.67000 \mathrm{E}-041.89255 \mathrm{E}-04$ method=2

pert073: $\mathrm{n}$ cell=1 mat=2 rho=9.598577845E-02 rxn=2 erg $=1.89255 \mathrm{E}-04 \quad 2.14454 \mathrm{E}-04$ method $=2$

pert074:n cell=1 mat=2 rho=9.598577845E-02 $r \times n=2$ erg $=2.14454 \mathrm{E}-042.43008 \mathrm{E}-04$ method=2

pert075: $\mathrm{n}$ cell=1 mat=2 rho=9.598577845E-02 rxn=2 erg $=2.43008 \mathrm{E}-042.75364 \mathrm{E}-04$ method $=2$

pert076:n cell=1 mat=2 rho=9.598577845E-02 $r \times n=2$ erg $=2.75364 \mathrm{E}-04 \quad 3.12029 \mathrm{E}-04$ method $=2$

pert077:n cell=1 mat=2 rho=9.598577845E-02 rxn=2 erg $=3.12029 \mathrm{E}-04 \quad 3.53575 \mathrm{E}-04$ method $=2$

pert078: $\mathrm{n}$ cell=1 mat=2 rho=9.598577845E-02 rxn=2 erg $=3.53575 \mathrm{E}-04 \quad 4.00653 \mathrm{E}-04$ method $=2$

pert079:n cell=1 mat=2 rho=9.598577845E-02 rxn=2 erg $=4.00653 \mathrm{E}-04 \quad 4.54000 \mathrm{E}-04$ method $=2$

pert080:n cell=1 mat=2 rho=9.598577845E-02 $r \times n=2$ erg $=4.54000 \mathrm{E}-045.14449 \mathrm{E}-04$ method $=2$ 
pert081: $\mathrm{n}$ cell=1 mat=2 rho=9.598577845E-02 rxn=2 erg $=5.14449 \mathrm{E}-045.82947 \mathrm{E}-04$ method $=2$

pert082: $\mathrm{n}$ cell=1 mat=2 rho=9.598577845E-02 rxn=2 erg $=5.82947 \mathrm{E}-04 \quad 6.60565 \mathrm{E}-04$ method=2

pert083:n cell=1 mat=2 rho=9.598577845E-02 rxn=2 erg $=6.60565 \mathrm{E}-04 \quad 7.48518 \mathrm{E}-04$ method $=2$

pert084:n cell=1 mat=2 rho=9.598577845E-02 $r \times n=2$ erg $=7.48518 \mathrm{E}-04$ 8.48182E-04 method $=2$

pert085:n cell=1 mat=2 rho=9.598577845E-02 $r \times n=2$ erg $=8.48182 \mathrm{E}-04 \quad 9.61117 \mathrm{E}-04$ method $=2$

pert086: $\mathrm{n}$ cell=1 mat=2 $r h o=9.598577845 \mathrm{E}-02 \mathrm{rxn}=2$ erg $=9.61117 \mathrm{E}-041.08909 \mathrm{E}-03$ method $=2$

pert087:n cell=1 mat=2 rho=9.598577845E-02 rxn=2 erg $=1.08909 \mathrm{E}-031.23500 \mathrm{E}-03$ method=2

pert088: $\mathrm{n}$ cell=1 mat=2 rho=9.598577845E-02 rxn=2 erg $=1.23500 \mathrm{E}-031.39842 \mathrm{E}-03$ method $=2$

pert089: $\mathrm{n}$ cell=1 mat=2 $\mathrm{rho}=9.598577845 \mathrm{E}-02 \mathrm{rxn}=2$ erg $=1.39842 \mathrm{E}-031.58461 \mathrm{E}-03$ method $=2$

pert090: $\mathrm{n}$ cell=1 mat=2 rho=9.598577845E-02 rxn=2 erg=1.58461E-03 1.79560E-03 method=2

pert091: $\mathrm{n}$ cell=1 mat=2 rho=9.598577845E-02 rxn=2 erg $=1.79560 \mathrm{E}-032.03468 \mathrm{E}-03$ method $=2$

pert092: $\mathrm{n}$ cell=1 mat=2 $\mathrm{rho}=9.598577845 \mathrm{E}-02 \mathrm{rxn}=2$ erg $=2.03468 \mathrm{E}-032.30560 \mathrm{E}-03$ method $=2$

pert093: $\mathrm{n}$ cell=1 mat=2 rho=9.598577845E-02 rxn=2 erg $=2.30560 \mathrm{E}-032.61259 \mathrm{E}-03$ method=2

pert094:n cell=1 mat=2 rho=9.598577845E-02 rxn=2 erg $=2.61259 \mathrm{E}-032.96045 \mathrm{E}-03$ method $=2$

pert095: n celle1 mat=2 rho=9.598577845E-02 rxn=2 erg $=2.96045 \mathrm{E}-03$ 3.35000E-03 method=2

pert096: $\mathrm{n}$ cell=1 mat=2 $r h o=9.598577845 \mathrm{E}-02 \mathrm{rxn}=2$ erg $=3.35000 \mathrm{E}-03 \quad 3.80129 \mathrm{E}-03$ method $=2$

pert097: $\mathrm{n}$ cell=1 mat=2 rho=9.598577845E-02 rxn=2 erg $=3.80129 \mathrm{E}-03 \quad 4.30743 \mathrm{E}-03$ method=2

pert098:n cell=1 mat=2 rho=9.598577845E-02 rxn=2 erg $=4.30743 \mathrm{E}-034.88095 \mathrm{E}-03$ method $=2$

pert099: n cell=1 mat=2 rho=9.598577845E-02 rxn=2 erg $=4.88095 \mathrm{E}-03 \quad 5.53084 \mathrm{E}-03$ method $=2$

pert $100: \mathrm{n}$ cell=1 mat=2 rho=9.598577845E-02 $r \times n=2$ erg $=5.53084 \mathrm{E}-03 \quad 6.26727 \mathrm{E}-03$ method=2

pert $101: \mathrm{n}$ cell=1 mat=2 rho=9.598577845E-02 rxn=2 erg $=6.26727 \mathrm{E}-03 \quad 7.10174 \mathrm{E}-03$ method $=2$

pert $102: \mathrm{n}$ cell=1 mat=2 rho=9.598577845E-02 rxn=2 erg $=7.10174 \mathrm{E}-038.04733 \mathrm{E}-03$ method $=2$

pert103:n cell=1 mat=2 rho=9.598577845E-02 rxn=2 erg $=8.04733 \mathrm{E}-039.12000 \mathrm{E}-03$ method=2

pert $104: \mathrm{n}$ cell=1 mat=2 rho=9.598577845E-02 rxn=2 erg $=9.12000 \mathrm{E}-031.03330 \mathrm{E}-02$ method=2

pert105: $\mathrm{n}$ cell=1 mat=2 rho=9.598577845E-02 $r \times n=2$ erg $=1.03330 \mathrm{E}-02 \quad 1.17088 \mathrm{E}-02$ method $=2$

pert106:n cell=1 mat=2 rho=9.598577845E-02 $r \times n=2$ erg $=1.17088 \mathrm{E}-021.32678 \mathrm{E}-02$ method=2

pert107:n cell=1 mat=2 rho=9.598577845E-02 rxn=2 erg $=1.32678 \mathrm{E}-021.50344 \mathrm{E}-02$ method=2

pert108: $\mathrm{n}$ cell=1 mat=2 rho=9.598577845E-02 $r \times n=2$ erg $=1.50344 \mathrm{E}-021.70362 \mathrm{E}-02$ method $=2$

pert109: $\mathrm{n}$ cell=1 mat=2 rho=9.598577845E-02 rxn=2 erg $=1.70362 \mathrm{E}-021.93045 \mathrm{E}-02$ method=2

pert $110: \mathrm{n}$ cell=1 mat=2 rho=9.598577845E-02 $r \times n=2$ erg $=1.93045 \mathrm{E}-02 \quad 2.18749 \mathrm{E}-02$ method=2

pert111:n cell=1 mat=2 rho=9.598577845E-02 $r \times n=2$ erg $=2.18749 \mathrm{E}-022.48000 \mathrm{E}-02$ method=2

pert 112 : n cell=1 mat=2 rho=9.598577845E-02 $r \times n=2$ erg $=2.48000 \mathrm{E}-022.80879 \mathrm{E}-02$ method $=2$

pert113:n cell=1 mat=2 rho=9.598577845E-02 rxn=2 erg $=2.80879 \mathrm{E}-02 \quad 3.18278 \mathrm{E}-02$ method $=2$

pert114:n cell=1 mat=2 rho=9.598577845E-02 rxn=2 erg $=3.18278 \mathrm{E}-02 \quad 3.60656 \mathrm{E}-02$ method $=2$

pert115: $\mathrm{n}$ cell=1 mat=2 rho=9.598577845E-02 rxn=2 erg $=3.60656 \mathrm{E}-02 \quad 4.08677 \mathrm{E}-02$ method $=2$

pert116:n cell=1 mat=2 rho=9.598577845E-02 rxn=2 erg $=4.08677 \mathrm{E}-02 \quad 4.63092 \mathrm{E}-02$ method=2

pert117: $\mathrm{n}$ cell=1 mat=2 rho=9.598577845E-02 $r \times n=2$ erg $=4.63092 \mathrm{E}-02 \quad 5.24752 \mathrm{E}-02$ method=2 
pert118: $\mathrm{n}$ cell=1 mat=2 rho=9.598577845E-02 rxn=2 erg $=5.24752 \mathrm{E}-02 \quad 5.94622 \mathrm{E}-02$ method $=2$

pert119: $\mathrm{n}$ cell=1 mat=2 rho=9.598577845E-02 rxn=2 erg $=5.94622 \mathrm{E}-02 \quad 6.76000 \mathrm{E}-02$ method $=2$

pert $120: \mathrm{n}$ cell=1 mat=2 rho=9.598577845E-02 rxn=2 erg $=6.76000 \mathrm{E}-027.63509 \mathrm{E}-02$ method $=2$

pert $121: \mathrm{n}$ cell=1 mat=2 rho=9.598577845E-02 $r \times n=2$ erg $=7.63509 \mathrm{E}-028.65170 \mathrm{E}-02$ method $=2$

pert122: n cell=1 mat=2 rho=9.598577845E-02 rxn=2 erg $=8.65170 \mathrm{E}-02 \quad 9.80366 \mathrm{E}-02$ method $=2$

pert $123: \mathrm{n}$ cell=1 mat=2 rho=9.598577845E-02 rxn=2 erg $=9.80366 \mathrm{E}-021.11090 \mathrm{E}-01$ method=2

pert $124: \mathrm{n}$ cell=1 mat=2 $r h o=9.598577845 \mathrm{E}-02 \quad r \times n=2$ erg $=1.11090 \mathrm{E}-01$ 1.25881E-01 method=2

pert $125: \mathrm{n}$ cell=1 mat=2 rho=9.598577845E-02 rxn=2 erg $=1.25881 \mathrm{E}-011.42642 \mathrm{E}-01$ method $=2$

pert $126: \mathrm{n}$ cell=1 mat=2 rho=9.598577845E-02 $r \times n=2$ erg $=1.42642 \mathrm{E}-01$ 1.61635E-01 method=2

pert $127: \mathrm{n}$ cell=1 mat=2 rho=9.598577845E-02 rxn=2 erg $=1.61635 \mathrm{E}-011.84000 \mathrm{E}-01$ method=2

pert128: $\mathrm{n}$ cell=1 mat=2 rho=9.598577845E-02 rxn=2 erg=1.84000E-01 1.94969E-01 method=2

pert $129: \mathrm{n}$ cell=1 mat=2 rho=9.598577845E-02 rxn=2 erg $=1.94969 \mathrm{E}-012.07543 \mathrm{E}-01$ method $=2$

pert $130: \mathrm{n}$ cell=1 mat=2 rho=9.598577845E-02 rxn=2 erg $=2.07543 \mathrm{E}-01 \quad 2.20929 \mathrm{E}-01$ method $=2$

pert $131: \mathrm{n}$ cell=1 mat=2 rho=9.598577845E-02 rxn=2 erg $=2.20929 \mathrm{E}-012.35177 \mathrm{E}-01$ method $=2$

pert132: n cell=1 mat=2 rho=9.598577845E-02 rxn=2 erg $=2.35177 \mathrm{E}-012.50345 \mathrm{E}-01$ method $=2$

pert $133: \mathrm{n}$ cell=1 mat=2 $r h o=9.598577845 \mathrm{E}-02 \mathrm{r} \times \mathrm{n}=2$ erg $=2.50345 \mathrm{E}-012.66491 \mathrm{E}-01$ method=2

pert $134: \mathrm{n}$ cell=1 mat=2 $r h o=9.598577845 \mathrm{E}-02 \mathrm{r} \times \mathrm{n}=2$ erg $=2.66491 \mathrm{E}-012.83678 \mathrm{E}-01$ method $=2$

pert $135: \mathrm{n}$ cell=1 mat=2 rho=9.598577845E-02 rxn=2 erg $=2.83678 \mathrm{E}-013.03000 \mathrm{E}-01$ method $=2$

pert136: $\mathrm{n}$ cell=1 mat=2 rho=9.598577845E-02 rxn=2 erg $=3.03000 \mathrm{E}-013.21449 \mathrm{E}-01$ method $=2$

pert137: $\mathrm{n}$ cell=1 mat=2 rho=9.598577845E-02 rxn=2 erg $=3.21449 \mathrm{E}-01 \quad 3.42181 \mathrm{E}-01$ method $=2$

pert138: $\mathrm{n}$ cell=1 mat=2 rho=9.598577845E-02 rxn=2 erg $=3.42181 \mathrm{E}-01 \quad 3.64250 \mathrm{E}-01$ method $=2$

pert139: $\mathrm{n}$ cell=1 mat=2 rho=9.598577845E-02 rxn=2 erg $=3.64250 \mathrm{E}-01 \quad 3.87742 \mathrm{E}-01$ method $=2$

pert $140: \mathrm{n}$ cell=1 mat=2 rho=9.598577845E-02 rxn=2 erg $=3.87742 \mathrm{E}-01 \quad 4.12749 \mathrm{E}-01$ method $=2$

pert $141: \mathrm{n}$ cell=1 mat=2 rho=9.598577845E-02 rxn=2 erg $=4.12749 \mathrm{E}-01 \quad 4.39369 \mathrm{E}-01$ method $=2$

pert $142: \mathrm{n}$ cell=1 mat=2 rho=9.598577845E-02 rxn=2 erg $=4.39369 \mathrm{E}-01 \quad 4.67706 \mathrm{E}-01$ method $=2$

pert $143: \mathrm{n}$ cell=1 mat=2 rho=9.598577845E-02 $r \times n=2$ erg $=4.67706 \mathrm{E}-015.00000 \mathrm{E}-01$ method $=2$

pert $144: \mathrm{n}$ cell=1 mat=2 rho=9.598577845E-02 rxn=2 erg $=5.00000 \mathrm{E}-015.29981 \mathrm{E}-01$ method=2

pert145:n cell=1 mat=2 rho=9.598577845E-02 rxn=2 erg $=5.29981 \mathrm{E}-01 \quad 5.64161 \mathrm{E}-01$ method $=2$

pert $146: \mathrm{n}$ cell=1 mat=2 rho=9.598577845E-02 rxn=2 erg $=5.64161 \mathrm{E}-01 \quad 6.00547 \mathrm{E}-01$ method $=2$

pert147:n cell=1 mat=2 rho=9.598577845E-02 rxn=2 erg $=6.00547 \mathrm{E}-01 \quad 6.39279 \mathrm{E}-01$ method $=2$

pert $148: \mathrm{n}$ cell=1 mat=2 rho=9.598577845E-02 rxn=2 erg $=6.39279 \mathrm{E}-01 \quad 6.80509 \mathrm{E}-01$ method $=2$

pert $149: \mathrm{n}$ cell=1 mat=2 $r h o=9.598577845 \mathrm{E}-02 \mathrm{rxn}=2$ erg $=6.80509 \mathrm{E}-017.24398 \mathrm{E}-01$ method $=2$

pert $150: \mathrm{n}$ cell=1 mat=2 rho=9.598577845E-02 $r \times n=2$ erg $=7.24398 \mathrm{E}-017.71117 \mathrm{E}-01$ method $=2$

pert151:n cell=1 mat=2 $r h o=9.598577845 \mathrm{E}-02 \mathrm{rxn}=2$ erg $=7.71117 \mathrm{E}-018.23000 \mathrm{E}-01$ method $=2$

pert $152: \mathrm{n}$ cell=1 mat=2 rho=9.598577845E-02 $\mathrm{rxn}=2$ erg $=8.23000 \mathrm{E}-018.73790 \mathrm{E}-01$ method $=2$

pert153:n cell=1 mat=2 rho=9.598577845E-02 $r \times n=2$ erg $=8.73790 \mathrm{E}-01 \quad 9.30145 \mathrm{E}-01$ method $=2$

pert154:n cell=1 mat=2 rho=9.598577845E-02 rxn=2 erg $=9.30145 \mathrm{E}-019.90134 \mathrm{E}-01$ method $=2$ 
pert $155: \mathrm{n}$ cell=1 mat=2 rho=9.598577845E-02 rxn=2 erg $=9.90134 \mathrm{E}-01 \quad 1.05399 \mathrm{E}+00$ method $=2$

pert156:n cell=1 mat=2 rho=9.598577845E-02 rxn=2 erg $=1.05399 \mathrm{E}+001.12197 \mathrm{E}+00$ method $=2$

pert $157: \mathrm{n}$ cell=1 mat=2 rho=9.598577845E-02 rxn=2 erg $=1.12197 \mathrm{E}+001.19433 \mathrm{E}+00$ method $=2$

pert 158: $\mathrm{n}$ cell=1 mat=2 rho=9.598577845E-02 rxn=2 erg $=1.19433 \mathrm{E}+001.27136 \mathrm{E}+00$ method $=2$

pert159:n cell=1 mat=2 rho=9.598577845E-02 rxn=2 erg $=1.27136 \mathrm{E}+001.35300 \mathrm{E}+00$ method $=2$

pert $160: \mathrm{n}$ cell=1 mat=2 rho=9.598577845E-02 rxn=2 erg $=1.35300 \mathrm{E}+001.39631 \mathrm{E}+00$ method=2

pert $161: \mathrm{n}$ cell=1 mat=2 $r h o=9.598577845 \mathrm{E}-02 \quad r \times n=2$ erg $=1.39631 \mathrm{E}+001.44064 \mathrm{E}+00$ method=2

pert $162: \mathrm{n}$ cell=1 mat=2 rho=9.598577845E-02 rxn=2 erg $=1.44064 \mathrm{E}+001.48637 \mathrm{E}+00$ method $=2$

pert $163: \mathrm{n}$ cell=1 mat=2 rho=9.598577845E-02 rxn=2 erg $=1.48637 \mathrm{E}+001.53355 \mathrm{E}+00$ method $=2$

pert $164: \mathrm{n}$ cell=1 mat=2 rho=9.598577845E-02 rxn=2 erg $=1.53355 \mathrm{E}+001.58223 \mathrm{E}+00$ method $=2$

pert $165: \mathrm{n}$ cell=1 mat=2 rho=9.598577845E-02 rxn=2 erg $=1.58223 \mathrm{E}+001.63246 \mathrm{E}+00$ method $=2$

pert $166: \mathrm{n}$ cell=1 mat=2 rho=9.598577845E-02 rxn=2 erg $=1.63246 \mathrm{E}+001.68427 \mathrm{E}+00$ method $=2$

pert $167: \mathrm{n}$ cell=1 mat=2 rho=9.598577845E-02 rxn=2 erg $=1.68427 \mathrm{E}+001.73800 \mathrm{E}+00$ method $=2$

pert $168: \mathrm{n}$ cell=1 mat=2 rho=9.598577845E-02 rxn=2 erg $=1.73800 \mathrm{E}+001.79290 \mathrm{E}+00$ method $=2$

pert 169:n cell=1 mat=2 rho=9.598577845E-02 rxn=2 erg $=1.79290 \mathrm{E}+001.84981 \mathrm{E}+00$ method $=2$

pert $170: \mathrm{n}$ cell=1 mat=2 $r h o=9.598577845 \mathrm{E}-02 \mathrm{r} \times \mathrm{n}=2$ erg $=1.84981 \mathrm{E}+001.90853 \mathrm{E}+00$ method=2

pert $171: \mathrm{n}$ cell=1 mat=2 rho=9.598577845E-02 rxn=2 erg $=1.90853 \mathrm{E}+001.96912 \mathrm{E}+00$ method $=2$

pert $172: \mathrm{n}$ cell=1 mat=2 rho=9.598577845E-02 rxn=2 erg $=1.96912 \mathrm{E}+002.03162 \mathrm{E}+00$ method $=2$

pert173: $\mathrm{n}$ cell=1 mat=2 rho=9.598577845E-02 rxn=2 erg $=2.03162 \mathrm{E}+002.09611 \mathrm{E}+00$ method $=2$

pert174: $\mathrm{n}$ cell=1 mat=2 rho=9.598577845E-02 rxn=2 erg $=2.09611 \mathrm{E}+002.16265 \mathrm{E}+00$ method=2

pert $175: \mathrm{n}$ cell=1 mat=2 rho=9.598577845E-02 rxn=2 erg $=2.16265 \mathrm{E}+002.23200 \mathrm{E}+00$ method $=2$

pert $176: \mathrm{n}$ cell=1 mat=2 rho=9.598577845E-02 rxn=2 erg $=2.23200 \mathrm{E}+002.30213 \mathrm{E}+00$ method $=2$

pert177:n cell=1 mat=2 rho=9.598577845E-02 rxn=2 erg $=2.30213 \mathrm{E}+002.37521 \mathrm{E}+00$ method $=2$

pert178:n cell=1 mat=2 rho=9.598577845E-02 $r \times n=2$ erg $=2.37521 \mathrm{E}+002.45061 \mathrm{E}+00$ method $=2$

pert 179: $\mathrm{n}$ cell=1 mat=2 rho=9.598577845E-02 rxn=2 erg $=2.45061 \mathrm{E}+002.52840 \mathrm{E}+00$ method $=2$

pert $180: \mathrm{n}$ cell=1 mat=2 rho=9.598577845E-02 $r \times n=2$ erg $=2.52840 \mathrm{E}+002.60866 \mathrm{E}+00$ method $=2$

pert181:n cell=1 mat=2 rho=9.598577845E-02 rxn=2 erg $=2.60866 \mathrm{E}+002.69146 \mathrm{E}+00$ method $=2$

pert182: $\mathrm{n}$ cell=1 mat=2 rho=9.598577845E-02 rxn=2 erg $=2.69146 \mathrm{E}+002.77690 \mathrm{E}+00$ method $=2$

pert $183: \mathrm{n}$ cell=1 mat=2 rho=9.598577845E-02 rxn=2 erg $=2.77690 \mathrm{E}+002.86500 \mathrm{E}+00$ method $=2$

pert $184: \mathrm{n}$ cell=1 mat=2 $r h o=9.598577845 \mathrm{E}-02 \mathrm{rxn}=2$ erg $=2.86500 \mathrm{E}+002.95599 \mathrm{E}+00$ method $=2$

pert $185: \mathrm{n}$ cell=1 mat=2 $r h o=9.598577845 \mathrm{E}-02 \mathrm{rxn}=2$ erg $=2.95599 \mathrm{E}+003.04983 \mathrm{E}+00$ method $=2$

pert $186: \mathrm{n}$ cell=1 mat=2 $r h o=9.598577845 \mathrm{E}-02 \mathrm{rxn}=2$ erg $=3.04983 \mathrm{E}+003.14664 \mathrm{E}+00$ method $=2$

pert187:n cell=1 mat=2 rho=9.598577845E-02 rxn=2 erg $=3.14664 \mathrm{E}+00 \quad 3.24652 \mathrm{E}+00$ method $=2$

pert188: $\mathrm{n}$ cell=1 mat=2 $\mathrm{rho}=9.598577845 \mathrm{E}-02 \quad \mathrm{rxn}=2$ erg $=3.24652 \mathrm{E}+00 \quad 3.34958 \mathrm{E}+00$ method $=2$

pert189:n cell=1 mat=2 rho=9.598577845E-02 $r \times n=2$ erg $=3.34958 \mathrm{E}+00 \quad 3.45591 \mathrm{E}+00$ method $=2$

pert190:n cell=1 mat=2 $r h o=9.598577845 \mathrm{E}-02 \mathrm{rxn}=2$ erg $=3.45591 \mathrm{E}+00 \quad 3.56561 \mathrm{E}+00$ method $=2$

pert191:n cell=1 mat=2 rho=9.598577845E-02 rxn=2 erg $=3.56561 \mathrm{E}+003.68000 \mathrm{E}+00$ method $=2$ 
pert192: $\mathrm{n}$ cell=1 mat=2 rho=9.598577845E-02 rxn=2 erg $=3.68000 \mathrm{E}+003.79557 \mathrm{E}+00$ method $=2$

pert193: $\mathrm{n}$ cell=1 mat=2 rho=9.598577845E-02 rxn=2 erg $=3.79557 \mathrm{E}+003.91606 \mathrm{E}+00$ method $=2$

pert194:n cell=1 mat=2 rho=9.598577845E-02 rxn=2 erg $=3.91606 \mathrm{E}+00 \quad 4.04037 \mathrm{E}+00$ method $=2$

pert $195: \mathrm{n}$ cell=1 mat=2 rho=9.598577845E-02 rxn=2 erg $=4.04037 \mathrm{E}+00 \quad 4.16862 \mathrm{E}+00$ method $=2$

pert196: $\mathrm{n}$ cell=1 mat=2 rho=9.598577845E-02 $r \times n=2$ erg $=4.16862 \mathrm{E}+00 \quad 4.30095 \mathrm{E}+00$ method $=2$

pert197: $\mathrm{n}$ cell=1 mat=2 rho=9.598577845E-02 rxn=2 erg $=4.30095 \mathrm{E}+004.43747 \mathrm{E}+00$ method $=2$

pert198: $\mathrm{n}$ cell=1 mat=2 $r h o=9.598577845 \mathrm{E}-02 \quad r \times n=2$ erg $=4.43747 \mathrm{E}+00 \quad 4.57833 \mathrm{E}+00$ method $=2$

pert199: $\mathrm{n}$ cell=1 mat=2 rho=9.598577845E-02 rxn=2 erg $=4.57833 \mathrm{E}+00 \quad 4.72367 \mathrm{E}+00$ method $=2$

pert $200: \mathrm{n}$ cell=1 mat=2 rho=9.598577845E-02 rxn=2 erg $=4.72367 \mathrm{E}+00 \quad 4.87361 \mathrm{E}+00$ method $=2$

pert $201: \mathrm{n}$ cell=1 mat=2 rho=9.598577845E-02 rxn=2 erg $=4.87361 \mathrm{E}+00 \quad 5.02832 \mathrm{E}+00$ method $=2$

pert202: $\mathrm{n}$ cell=1 mat=2 rho=9.598577845E-02 rxn=2 erg $=5.02832 \mathrm{E}+00 \quad 5.18793 \mathrm{E}+00$ method $=2$

pert $203: \mathrm{n}$ cell=1 mat=2 rho=9.598577845E-02 rxn=2 erg $=5.18793 \mathrm{E}+005.35261 \mathrm{E}+00$ method $=2$

pert204:n cell=1 mat=2 rho=9.598577845E-02 rxn=2 erg $=5.35261 \mathrm{E}+00 \quad 5.52252 \mathrm{E}+00$ method $=2$

pert205:n cell=1 mat=2 rho=9.598577845E-02 rxn=2 erg $=5.52252 \mathrm{E}+00 \quad 5.69783 \mathrm{E}+00$ method $=2$

pert206:n cell=1 mat=2 rho=9.598577845E-02 rxn=2 erg $=5.69783 \mathrm{E}+005.87870 \mathrm{E}+00$ method $=2$

pert $207: \mathrm{n}$ cell=1 mat=2 rho=9.598577845E-02 $r \times n=2$ erg $=5.87870 \mathrm{E}+006.07000 \mathrm{E}+00$ method $=2$

pert 208:n cell=1 mat=2 rho=9.598577845E-02 rxn=2 erg $=6.07000 \mathrm{E}+006.25784 \mathrm{E}+00$ method $=2$

pert 209: $\mathrm{n}$ cell=1 mat=2 rho=9.598577845E-02 rxn=2 erg $=6.25784 \mathrm{E}+006.45649 \mathrm{E}+00$ method $=2$

pert $210: \mathrm{n}$ cell=1 mat=2 rho=9.598577845E-02 rxn=2 erg $=6.45649 \mathrm{E}+00 \quad 6.66144 \mathrm{E}+00$ method $=2$

pert $211: \mathrm{n}$ cell=1 mat=2 rho=9.598577845E-02 rxn=2 erg $=6.66144 \mathrm{E}+006.87289 \mathrm{E}+00$ method $=2$

pert 212 : $n$ cell=1 mat=2 rho=9.598577845E-02 rxn=2 erg $=6.87289 \mathrm{E}+007.09106 \mathrm{E}+00$ method $=2$

pert $213: \mathrm{n}$ cell=1 mat=2 rho=9.598577845E-02 rxn=2 erg $=7.09106 \mathrm{E}+007.31616 \mathrm{E}+00$ method $=2$

pert214:n cell=1 mat=2 rho=9.598577845E-02 rxn=2 erg $=7.31616 \mathrm{E}+007.54840 \mathrm{E}+00$ method $=2$

pert $215: \mathrm{n}$ cell=1 mat=2 $r h o=9.598577845 \mathrm{E}-02 \mathrm{rxn}=2$ erg $=7.54840 \mathrm{E}+007.79000 \mathrm{E}+00$ method $=2$

pert216:n cell=1 mat=2 rho=9.598577845E-02 rxn=2 erg $=7.79000 \mathrm{E}+008.03523 \mathrm{E}+00$ method $=2$

pert $217: \mathrm{n}$ cell=1 mat=2 rho=9.598577845E-02 $r \times n=2$ erg $=8.03523 \mathrm{E}+00 \quad 8.29029 \mathrm{E}+00$ method $=2$

pert218: $\mathrm{n}$ cell=1 mat=2 rho=9.598577845E-02 rxn=2 erg $=8.29029 \mathrm{E}+00 \quad 8.55345 \mathrm{E}+00$ method $=2$

pert219:n cell=1 mat=2 rho=9.598577845E-02 rxn=2 erg $=8.55345 \mathrm{E}+00 \quad 8.82497 \mathrm{E}+00$ method $=2$

pert $220: \mathrm{n}$ cell=1 mat=2 rho=9.598577845E-02 rxn=2 erg $=8.82497 \mathrm{E}+00 \quad 9.10510 \mathrm{E}+00$ method $=2$

pert $221: \mathrm{n}$ cell=1 mat=2 rho=9.598577845E-02 $r \times n=2$ erg $=9.10510 \mathrm{E}+00$ 9.39413E+00 method $=2$

pert $222: \mathrm{n}$ cell=1 mat=2 rho=9.598577845E-02 rxn=2 erg $=9.39413 \mathrm{E}+00 \quad 9.69233 \mathrm{E}+00$ method $=2$

pert $223: \mathrm{n}$ cell=1 mat=2 $r h o=9.598577845 \mathrm{E}-02 \mathrm{rxn}=2$ erg $=9.69233 \mathrm{E}+001.00000 \mathrm{E}+01$ method $=2$

pert $224: \mathrm{n}$ cell=1 mat=2 rho=9.598577845E-02 rxn=2 erg $=1.00000 \mathrm{E}+011.02500 \mathrm{E}+01$ method $=2$

pert $225: \mathrm{n}$ cell=1 mat=2 $\mathrm{rho}=9.598577845 \mathrm{E}-02 \quad \mathrm{rxn}=2$ erg $=1.02500 \mathrm{E}+01 \quad 1.05000 \mathrm{E}+01$ method=2

pert226:n cell=1 mat=2 rho=9.598577845E-02 rxn=2 erg $=1.05000 \mathrm{E}+01 \quad 1.07500 \mathrm{E}+01$ method $=2$

pert227:n cell=1 mat=2 rho=9.598577845E-02 rxn=2 erg $=1.07500 \mathrm{E}+01$ 1.10000E +01 method $=2$

pert228: $\mathrm{n}$ cell=1 mat=2 rho=9.598577845E-02 rxn=2 erg=1.10000E+01 1.12500E+01 method=2 
pert229: $\mathrm{n}$ cell=1 mat=2 rho=9.598577845E-02 rxn=2 erg $=1.12500 \mathrm{E}+011.15000 \mathrm{E}+01$ method $=2$

pert230:n cell=1 mat=2 rho=9.598577845E-02 rxn=2 erg $=1.15000 \mathrm{E}+01$ 1.17500E +01 method $=2$

pert $231: \mathrm{n}$ cell=1 mat=2 rho=9.598577845E-02 rxn=2 erg $=1.17500 \mathrm{E}+01$ 1.20000E+01 method $=2$

pert $232: \mathrm{n}$ cell=1 mat=2 rho=9.598577845E-02 $r \times n=2$ erg $=1.20000 \mathrm{E}+01$ 1.22500E+01 method=2

pert233: $\mathrm{n}$ cell=1 mat=2 rho=9.598577845E-02 rxn=2 erg $=1.22500 \mathrm{E}+01$ 1.25000E+01 method $=2$

pert $234: \mathrm{n}$ cell=1 mat=2 rho=9.598577845E-02 rxn=2 erg=1.25000E+01 1.27500E+01 method=2

pert $235: \mathrm{n}$ cell=1 mat=2 $r h o=9.598577845 \mathrm{E}-02 \quad r \times n=2$ erg=1.27500E+01 1.30000E+01 method=2

pert $236: \mathrm{n}$ cell=1 mat=2 $r h o=9.598577845 \mathrm{E}-02 \mathrm{r} \times \mathrm{n}=2$ erg $=1.30000 \mathrm{E}+011.32500 \mathrm{E}+01$ method $=2$

pert $237: \mathrm{n}$ cell=1 mat=2 rho=9.598577845E-02 rxn=2 erg $=1.32500 \mathrm{E}+01$ 1.35000E+01 method=2

pert $238: \mathrm{n}$ cell=1 mat=2 rho=9.598577845E-02 rxn=2 erg $=1.35000 \mathrm{E}+011.37500 \mathrm{E}+01$ method $=2$

pert239: $\mathrm{n}$ cell=1 mat=2 rho=9.598577845E-02 rxn=2 erg $=1.37500 \mathrm{E}+01$ 1.40000E+01 method $=2$

pert $240: \mathrm{n}$ cell=1 mat=2 rho=9.598577845E-02 rxn=2 erg $=1.40000 \mathrm{E}+01$ 1.42500E+01 method $=2$

pert $241: \mathrm{n}$ cell=1 mat=2 rho=9.598577845E-02 rxn=2 erg $=1.42500 \mathrm{E}+01$ 1.45000E+01 method $=2$

pert $242: \mathrm{n}$ cell=1 mat=2 rho=9.598577845E-02 rxn=2 erg $=1.45000 \mathrm{E}+01$ 1.47500E+01 method $=2$

pert $243: \mathrm{n}$ celle1 mat=2 rho=9.598577845E-02 rxn=2 erg $=1.47500 \mathrm{E}+01$ 1.50000E+01 method=2

pert $244: \mathrm{n}$ cell=1 mat=2 rho=9.598577845E-02 rxn=2 erg $=1.50000 \mathrm{E}+01$ 1.52500E+01 method=2

pert $245: \mathrm{n}$ cell=1 mat=2 rho=9.598577845E-02 rxn=2 erg $=1.52500 \mathrm{E}+01$ 1.55000E+01 method=2

pert $246: \mathrm{n}$ cell=1 mat=2 rho=9.598577845E-02 rxn=2 erg=1.55000E+01 1.57500E+01 method=2

pert $247: \mathrm{n}$ cell=1 mat=2 rho=9.598577845E-02 rxn=2 erg $=1.57500 \mathrm{E}+011.60000 \mathrm{E}+01$ method=2

pert $248: \mathrm{n}$ cell=1 mat=2 rho=9.598577845E-02 rxn=2 erg $=1.60000 \mathrm{E}+01$ 1.62500E+01 method $=2$

pert $249: \mathrm{n}$ cell=1 mat=2 rho=9.598577845E-02 rxn=2 erg $=1.62500 \mathrm{E}+01$ 1.65000E+01 method $=2$

pert $250: \mathrm{n}$ cell=1 mat=2 rho=9.598577845E-02 rxn=2 erg=1.65000E+01 1.67500E+01 method=2

pert251:n cell=1 mat=2 rho=9.598577845E-02 rxn=2 erg $=1.67500 \mathrm{E}+01 \quad 1.70000 \mathrm{E}+01$ method $=2$

pert601:n cell=1 mat=2 rho=9.598577845E-02 rxn=51 39I 91 erg $=0.00000 \mathrm{E}+001.39000 \mathrm{E}-10$ method $=2$

pert $602: \mathrm{n}$ cell=1 mat=2 rho=9.598577845E-02 rxn=51 $39 \mathrm{I} 91$ erg $=1.39000 \mathrm{E}-102.43741 \mathrm{E}-10$ method $=2$

pert603: $\mathrm{n}$ cell=1 mat=2 rho=9.598577845E-02 rxn=51 39I 91 erg $=2.43741 \mathrm{E}-10 \quad 4.01861 \mathrm{E}-10$ method $=2$

pert $604: \mathrm{n}$ cell=1 mat=2 rho=9.598577845E-02 rxn=51 39I 91 erg $=4.01861 \mathrm{E}-10 \quad 6.62557 \mathrm{E}-10$ method $=2$

pert605:n cell=1 mat=2 rho=9.598577845E-02 rxn=51 39I 91 erg $=6.62557 \mathrm{E}-101.09237 \mathrm{E}-09$ method $=2$

pert $606: \mathrm{n}$ cell=1 mat=2 rho=9.598577845E-02 rxn=51 39I 91 erg $=1.09237 \mathrm{E}-091.80102 \mathrm{E}-09$ method $=2$

pert607:n cell=1 mat=2 rho=9.598577845E-02 rxn=51 39I 91 erg $=1.80102 \mathrm{E}-092.96937 \mathrm{E}-09$ method $=2$

pert608:n cell=1 mat=2 rho=9.598577845E-02 rxn=51 39I 91 erg $=2.96937 \mathrm{E}-09 \quad 4.89567 \mathrm{E}-09$ method $=2$

pert609:n cell=1 mat=2 rho=9.598577845E-02 rxn=51 39I 91 erg $=4.89567 \mathrm{E}-09$ 8.07159E-09 method $=2$

pert610:n cell=1 mat=2 rho=9.598577845E-02 rxn=51 39I 91 erg $=8.07159 \mathrm{E}-091.25015 \mathrm{E}-08$ method $=2$

pert611:n cell=1 mat=2 rho=9.598577845E-02 rxn=51 39I 91 erg $=1.25015 \mathrm{E}-08 \quad 2.06115 \mathrm{E}-08$ method $=2$

pert612: n cell=1 mat=2 rho=9.598577845E-02 rxn=51 39I 91 erg $=2.06115 \mathrm{E}-08 \quad 3.39827 \mathrm{E}-08$ method $=2$

pert613: $\mathrm{n}$ cell=1 mat=2 rho=9.598577845E-02 rxn=51 39I 91 erg $=3.39827 \mathrm{E}-08 \quad 5.60280 \mathrm{E}-08$ method $=2$

pert614:n cell=1 mat=2 rho=9.598577845E-02 rxn=51 39I 91 erg $=5.60280 \mathrm{E}-08$ 9.23745E-08 method $=2$ 
pert615: $\mathrm{n}$ cell=1 mat=2 rho=9.598577845E-02 rxn=51 39I 91 erg $=9.23745 \mathrm{E}-08 \quad 1.52000 \mathrm{E}-07$ method $=2$

pert616:n cell=1 mat=2 rho=9.598577845E-02 rxn=51 39I 91 erg $=1.52000 \mathrm{E}-07 \quad 1.72578 \mathrm{E}-07$ method $=2$

pert617:n cell=1 mat=2 rho=9.598577845E-02 rxn=51 39I 91 erg $=1.72578 \mathrm{E}-07 \quad 1.95557 \mathrm{E}-07$ method $=2$

pert618:n cell=1 mat=2 rho=9.598577845E-02 rxn=51 39I 91 erg $=1.95557 \mathrm{E}-07 \quad 2.21595 \mathrm{E}-07$ method $=2$

pert619: $\mathrm{n}$ cell=1 mat=2 rho=9.598577845E-02 rxn=51 39I 91 erg $=2.21595 \mathrm{E}-07 \quad 2.51100 \mathrm{E}-07$ method $=2$

pert $620: \mathrm{n}$ cell=1 mat=2 rho=9.598577845E-02 rxn=51 39I 91 erg $=2.51100 \mathrm{E}-07 \quad 2.84533 \mathrm{E}-07$ method=2

pert621:n cell=1 mat=2 rho=9.598577845E-02 rxn=51 39I 91 erg $=2.84533 \mathrm{E}-07 \quad 3.22419 \mathrm{E}-07$ method $=2$

pert $622: \mathrm{n}$ cell=1 mat=2 rho=9.598577845E-02 rxn=51 39I 91 erg $=3.22419 \mathrm{E}-07 \quad 3.65348 \mathrm{E}-07$ method $=2$

pert623:n cell=1 mat=2 rho=9.598577845E-02 rxn=51 39I 91 erg $=3.65348 \mathrm{E}-07 \quad 4.14000 \mathrm{E}-07$ method $=2$

pert $624: \mathrm{n}$ cell=1 mat=2 rho=9.598577845E-02 rxn=51 $39 \mathrm{I} 91$ erg $=4.14000 \mathrm{E}-07 \quad 4.69116 \mathrm{E}-07$ method $=2$

pert $625: \mathrm{n}$ cell=1 mat=2 rho=9.598577845E-02 rxn=51 39191 erg $=4.69116 \mathrm{E}-07 \quad 5.31579 \mathrm{E}-07$ method $=2$

pert626:n cell=1 mat=2 rho=9.598577845E-02 rxn=51 39191 erg $=5.31579 \mathrm{E}-07 \quad 6.02357 \mathrm{E}-07$ method $=2$

pert627:n cell=1 mat=2 rho=9.598577845E-02 rxn=51 39191 erg $=6.02357 \mathrm{E}-07 \quad 6.82560 \mathrm{E}-07$ method $=2$

pert628:n cell=1 mat=2 rho=9.598577845E-02 rxn=51 39I 91 erg $=6.82560 \mathrm{E}-07 \quad 7.73442 \mathrm{E}-07$ method $=2$

pert629:n cell=1 mat=2 rho=9.598577845E-02 rxn=51 39I 91 erg $=7.73442 \mathrm{E}-07$ 8.76425E-07 method $=2$

pert $630: \mathrm{n}$ cell=1 mat=2 rho=9.598577845E-02 rxn=51 39I 91 erg $=8.76425 \mathrm{E}-07 \quad 9.93119 \mathrm{E}-07$ method $=2$

pert631:n cell=1 mat=2 rho=9.598577845E-02 rxn=51 39I 91 erg $=9.93119 \mathrm{E}-07 \quad 1.13000 \mathrm{E}-06$ method=2

pert632: $\mathrm{n}$ cell=1 mat=2 rho=9.598577845E-02 rxn=51 39I 91 erg $=1.13000 \mathrm{E}-06 \quad 1.27519 \mathrm{E}-06$ method $=2$

pert633:n cell=1 mat=2 rho=9.598577845E-02 rxn=51 39I 91 erg $=1.27519 \mathrm{E}-061.44498 \mathrm{E}-06$ method $=2$

pert $634: \mathrm{n}$ cell=1 mat=2 rho=9.598577845E-02 rxn=51 $39 \mathrm{I} 91$ erg=1.44498E-06 1.63738E-06 method=2

pert $635: \mathrm{n}$ cell=1 mat=2 rho=9.598577845E-02 rxn=51 39I 91 erg $=1.63738 \mathrm{E}-061.85539 \mathrm{E}-06$ method=2

pert636: $\mathrm{n}$ cell=1 mat=2 rho=9.598577845E-02 rxn=51 $39 \mathrm{I} 91$ erg $=1.85539 \mathrm{E}-062.10243 \mathrm{E}-06$ method $=2$

pert637:n cell=1 mat=2 rho=9.598577845E-02 rxn=51 39I 91 erg $=2.10243 \mathrm{E}-062.38237 \mathrm{E}-06$ method $=2$

pert638:n cell=1 mat=2 rho=9.598577845E-02 rxn=51 39I 91 erg $=2.38237 \mathrm{E}-062.69958 \mathrm{E}-06$ method $=2$

pert $639: \mathrm{n}$ cell=1 mat=2 rho=9.598577845E-02 rxn=51 $39 \mathrm{I} 91$ erg $=2.69958 \mathrm{E}-063.06000 \mathrm{E}-06$ method $=2$

pert $640: \mathrm{n}$ cell=1 mat=2 rho=9.598577845E-02 rxn=51 39I 91 erg $=3.06000 \mathrm{E}-06 \quad 3.46633 \mathrm{E}-06$ method $=2$

pert $641: \mathrm{n}$ cell=1 mat=2 rho=9.598577845E-02 rxn=51 39I 91 erg $=3.46633 \mathrm{E}-063.92786 \mathrm{E}-06$ method $=2$

pert $642: \mathrm{n}$ cell=1 mat=2 rho=9.598577845E-02 rxn=51 39I 91 erg $=3.92786 \mathrm{E}-06 \quad 4.45085 \mathrm{E}-06$ method $=2$

pert $643: \mathrm{n}$ cell=1 mat=2 rho=9.598577845E-02 rxn=51 39I 91 erg $=4.45085 \mathrm{E}-065.04348 \mathrm{E}-06$ method $=2$

pert $644: \mathrm{n}$ cell=1 mat=2 rho=9.598577845E-02 rxn=51 39I 91 erg $=5.04348 \mathrm{E}-065.71501 \mathrm{E}-06$ method $=2$

pert $645: \mathrm{n}$ cell=1 mat=2 rho=9.598577845E-02 rxn=51 $39 \mathrm{I} 91$ erg $=5.71501 \mathrm{E}-06$ 6.47595E-06 method $=2$

pert $646: \mathrm{n}$ cell=1 mat=2 rho=9.598577845E-02 rxn=51 39I 91 erg $=6.47595 \mathrm{E}-067.33822 \mathrm{E}-06$ method $=2$

pert647:n cell=1 mat=2 rho=9.598577845E-02 rxn=51 39I 91 erg $=7.33822 \mathrm{E}-068.32000 \mathrm{E}-06$ method $=2$

pert $648: \mathrm{n}$ cell=1 mat=2 rho=9.598577845E-02 rxn=51 39I 91 erg $=8.32000 \mathrm{E}-069.42245 \mathrm{E}-06$ method $=2$

pert $649: \mathrm{n}$ cell=1 mat=2 rho=9.598577845E-02 rxn=51 39I 91 erg $=9.42245 \mathrm{E}-061.06770 \mathrm{E}-05$ method $=2$

pert650:n cell=1 mat=2 rho=9.598577845E-02 rxn=51 39I 91 erg $=1.06770 \mathrm{E}-051.20987 \mathrm{E}-05$ method $=2$

pert651:n cell=1 mat=2 rho=9.598577845E-02 rxn=51 39I 91 erg $=1.20987 \mathrm{E}-051.37096 \mathrm{E}-05$ method=2 
pert652: $\mathrm{n}$ cell=1 mat=2 rho=9.598577845E-02 rxn=51 39I 91 erg $=1.37096 \mathrm{E}-051.55350 \mathrm{E}-05$ method $=2$

pert653:n cell=1 mat=2 rho=9.598577845E-02 rxn=51 39I 91 erg $=1.55350 \mathrm{E}-051.76035 \mathrm{E}-05$ method $=2$

pert $654: \mathrm{n}$ cell=1 mat=2 rho=9.598577845E-02 rxn=51 39I 91 erg $=1.76035 \mathrm{E}-051.99473 \mathrm{E}-05$ method $=2$

pert655: $\mathrm{n}$ cell=1 mat=2 rho=9.598577845E-02 rxn=51 39I 91 erg $=1.99473 \mathrm{E}-052.26000 \mathrm{E}-05$ method $=2$

pert656:n cell=1 mat=2 rho=9.598577845E-02 rxn=51 39I 91 erg $=2.26000 \mathrm{E}-052.56129 \mathrm{E}-05$ method $=2$

pert657:n cell=1 mat=2 rho=9.598577845E-02 rxn=51 39I 91 erg $=2.56129 \mathrm{E}-052.90232 \mathrm{E}-05$ method=2

pert658:n cell=1 mat=2 rho=9.598577845E-02 rxn=51 39I 91 erg $=2.90232 \mathrm{E}-053.28876 \mathrm{E}-05$ method $=2$

pert $659: \mathrm{n}$ cell=1 mat=2 rho=9.598577845E-02 rxn=51 39I 91 erg $=3.28876 \mathrm{E}-053.72665 \mathrm{E}-05$ method $=2$

pert $660: \mathrm{n}$ cell=1 mat=2 rho=9.598577845E-02 rxn=51 39I 91 erg $=3.72665 \mathrm{E}-05 \quad 4.22285 \mathrm{E}-05$ method $=2$

pert661:n cell=1 mat=2 rho=9.598577845E-02 rxn=51 $39 \mathrm{I} 91$ erg $=4.22285 \mathrm{E}-05 \quad 4.78512 \mathrm{E}-05$ method $=2$

pert662: $\mathrm{n}$ cell=1 mat=2 rho=9.598577845E-02 rxn=51 39I 91 erg $=4.78512 \mathrm{E}-05 \quad 5.42225 \mathrm{E}-05$ method $=2$

pert663: $\mathrm{n}$ cell=1 mat=2 rho=9.598577845E-02 rxn=51 $39 \mathrm{I} 91$ erg $=5.42225 \mathrm{E}-05 \quad 6.14000 \mathrm{E}-05$ method $=2$

pert664:n cell=1 mat=2 rho=9.598577845E-02 rxn=51 39I 91 erg $=6.14000 \mathrm{E}-056.96230 \mathrm{E}-05$ method $=2$

pert665:n cell=1 mat=2 rho=9.598577845E-02 rxn=51 39I 91 erg $=6.96230 \mathrm{E}-057.88932 \mathrm{E}-05$ method $=2$

pert $666: \mathrm{n}$ cell=1 mat=2 rho=9.598577845E-02 rxn=51 39I 91 erg $=7.88932 \mathrm{E}-058.93978 \mathrm{E}-05$ method $=2$

pert667:n cell=1 mat=2 rho=9.598577845E-02 rxn=51 39I 91 erg $=8.93978 \mathrm{E}-051.01301 \mathrm{E}-04$ method $=2$

pert668:n cell=1 mat=2 rho=9.598577845E-02 rxn=51 39I 91 erg=1.01301E-04 1.14789E-04 method=2

pert $669: \mathrm{n}$ cell=1 mat=2 rho=9.598577845E-02 rxn=51 39I 91 erg $=1.14789 \mathrm{E}-041.30073 \mathrm{E}-04$ method $=2$

pert $670: \mathrm{n}$ cell=1 mat=2 rho=9.598577845E-02 rxn=51 39I 91 erg $=1.30073 \mathrm{E}-041.47392 \mathrm{E}-04$ method=2

pert $671: \mathrm{n}$ cell=1 mat=2 rho=9.598577845E-02 rxn=51 $39 \mathrm{I} 91$ erg $=1.47392 \mathrm{E}-04 \quad 1.67000 \mathrm{E}-04$ method $=2$

pert $672: \mathrm{n}$ cell=1 mat=2 rho=9.598577845E-02 rxn=51 39I 91 erg $=1.67000 \mathrm{E}-041.89255 \mathrm{E}-04$ method $=2$

pert673:n cell=1 mat=2 rho=9.598577845E-02 rxn=51 39I 91 erg $=1.89255 \mathrm{E}-042.14454 \mathrm{E}-04$ method=2

pert674:n cell=1 mat=2 rho=9.598577845E-02 rxn=51 39I 91 erg $=2.14454 \mathrm{E}-04 \quad 2.43008 \mathrm{E}-04$ method $=2$

pert675: $\mathrm{n}$ cell=1 mat=2 rho=9.598577845E-02 rxn=51 39I 91 erg $=2.43008 \mathrm{E}-042.75364 \mathrm{E}-04$ method $=2$

pert $676: \mathrm{n}$ cell=1 mat=2 rho=9.598577845E-02 rxn=51 $39 \mathrm{I} 91$ erg $=2.75364 \mathrm{E}-04 \quad 3.12029 \mathrm{E}-04$ method $=2$

pert677:n cell=1 mat=2 rho=9.598577845E-02 rxn=51 39I 91 erg $=3.12029 \mathrm{E}-04 \quad 3.53575 \mathrm{E}-04$ method $=2$

pert678:n cell=1 mat=2 rho=9.598577845E-02 rxn=51 39I 91 erg $=3.53575 \mathrm{E}-04 \quad 4.00653 \mathrm{E}-04$ method $=2$

pert679: $\mathrm{n}$ cell=1 mat=2 rho=9.598577845E-02 rxn=51 39I 91 erg $=4.00653 \mathrm{E}-04 \quad 4.54000 \mathrm{E}-04$ method $=2$

pert $680: \mathrm{n}$ cell=1 mat=2 rho=9.598577845E-02 rxn=51 39I 91 erg $=4.54000 \mathrm{E}-045.14449 \mathrm{E}-04$ method $=2$

pert681:n cell=1 mat=2 rho=9.598577845E-02 rxn=51 39I 91 erg $=5.14449 \mathrm{E}-045.82947 \mathrm{E}-04$ method $=2$

pert682: $\mathrm{n}$ cell=1 mat=2 rho=9.598577845E-02 rxn=51 39191 erg $=5.82947 \mathrm{E}-04 \quad 6.60565 \mathrm{E}-04$ method $=2$

pert683: $\mathrm{n}$ cell=1 mat=2 rho=9.598577845E-02 rxn=51 39I 91 erg $=6.60565 \mathrm{E}-047.48518 \mathrm{E}-04$ method $=2$

pert $684: \mathrm{n}$ cell=1 mat=2 rho=9.598577845E-02 rxn=51 39I 91 erg $=7.48518 \mathrm{E}-048.48182 \mathrm{E}-04$ method $=2$

pert $685: \mathrm{n}$ cell=1 mat=2 rho=9.598577845E-02 rxn=51 $39 \mathrm{I} 91$ erg $=8.48182 \mathrm{E}-04 \quad 9.61117 \mathrm{E}-04$ method $=2$

pert686:n cell=1 mat=2 rho=9.598577845E-02 rxn=51 39I 91 erg $=9.61117 \mathrm{E}-041.08909 \mathrm{E}-03$ method $=2$

pert687:n cell=1 mat=2 rho=9.598577845E-02 rxn=51 39I 91 erg $=1.08909 \mathrm{E}-031.23500 \mathrm{E}-03$ method $=2$

pert688:n cell=1 mat=2 rho=9.598577845E-02 rxn=51 39I 91 erg $=1.23500 \mathrm{E}-03 \quad 1.39842 \mathrm{E}-03$ method=2 
pert689: $\mathrm{n}$ cell=1 mat=2 rho=9.598577845E-02 rxn=51 39I 91 erg $=1.39842 \mathrm{E}-03 \quad 1.58461 \mathrm{E}-03$ method $=2$

pert690:n cell=1 mat=2 rho=9.598577845E-02 rxn=51 39I 91 erg $=1.58461 \mathrm{E}-03 \quad 1.79560 \mathrm{E}-03$ method $=2$

pert691:n cell=1 mat=2 rho=9.598577845E-02 rxn=51 39I 91 erg $=1.79560 \mathrm{E}-032.03468 \mathrm{E}-03$ method $=2$

pert692: $\mathrm{n}$ cell=1 mat=2 rho=9.598577845E-02 rxn=51 39I 91 erg $=2.03468 \mathrm{E}-032.30560 \mathrm{E}-03$ method $=2$

pert693: $\mathrm{n}$ cell=1 mat=2 rho=9.598577845E-02 rxn=51 39I 91 erg $=2.30560 \mathrm{E}-03 \quad 2.61259 \mathrm{E}-03$ method $=2$

pert $694: \mathrm{n}$ cell=1 mat=2 rho=9.598577845E-02 rxn=51 39I 91 erg $=2.61259 \mathrm{E}-032.96045 \mathrm{E}-03$ method=2

pert695:n cell=1 mat=2 rho=9.598577845E-02 rxn=51 39I 91 erg $=2.96045 \mathrm{E}-03 \quad 3.35000 \mathrm{E}-03$ method=2

pert $696: \mathrm{n}$ cell=1 mat=2 rho=9.598577845E-02 rxn=51 39I 91 erg $=3.35000 \mathrm{E}-033.80129 \mathrm{E}-03$ method $=2$

pert697:n cell=1 mat=2 rho=9.598577845E-02 rxn=51 39I 91 erg $=3.80129 \mathrm{E}-03 \quad 4.30743 \mathrm{E}-03$ method $=2$

pert698: $\mathrm{n}$ cell=1 mat=2 rho=9.598577845E-02 rxn=51 $39 \mathrm{I} 91$ erg $=4.30743 \mathrm{E}-03 \quad 4.88095 \mathrm{E}-03$ method $=2$

pert699:n cell=1 mat=2 rho=9.598577845E-02 rxn=51 39191 erg $=4.88095 \mathrm{E}-03 \quad 5.53084 \mathrm{E}-03$ method $=2$

pert700:n cell=1 mat=2 rho=9.598577845E-02 rxn=51 39191 erg $=5.53084 \mathrm{E}-03 \quad 6.26727 \mathrm{E}-03$ method $=2$

pert701:n cell=1 mat=2 rho=9.598577845E-02 rxn=51 39191 erg $=6.26727 \mathrm{E}-03 \quad 7.10174 \mathrm{E}-03$ method $=2$

pert702: $\mathrm{n}$ cell=1 mat=2 rho=9.598577845E-02 rxn=51 39I 91 erg $=7.10174 \mathrm{E}-03 \quad 8.04733 \mathrm{E}-03$ method $=2$

pert703:n cell=1 mat=2 rho=9.598577845E-02 rxn=51 39I 91 erg $=8.04733 \mathrm{E}-03 \quad 9.12000 \mathrm{E}-03$ method $=2$

pert704:n cell=1 mat=2 rho=9.598577845E-02 rxn=51 39I 91 erg $=9.12000 \mathrm{E}-03 \quad 1.03330 \mathrm{E}-02$ method=2

pert705: $\mathrm{n}$ cell=1 mat=2 rho=9.598577845E-02 rxn=51 39I 91 erg=1.03330E-02 1.17088E-02 method=2

pert706:n cell=1 mat=2 rho=9.598577845E-02 rxn=51 39I 91 erg $=1.17088 \mathrm{E}-02 \quad 1.32678 \mathrm{E}-02$ method $=2$

pert707:n cell=1 mat=2 rho=9.598577845E-02 rxn=51 39I 91 erg $=1.32678 \mathrm{E}-02 \quad 1.50344 \mathrm{E}-02$ method=2

pert708: $\mathrm{n}$ cell=1 mat=2 rho=9.598577845E-02 rxn=51 $39 \mathrm{I} 91$ erg $=1.50344 \mathrm{E}-021.70362 \mathrm{E}-02$ method $=2$

pert709: $\mathrm{n}$ cell=1 mat=2 rho=9.598577845E-02 rxn=51 39I 91 erg $=1.70362 \mathrm{E}-021.93045 \mathrm{E}-02$ method=2

pert710:n cell=1 mat=2 rho=9.598577845E-02 rxn=51 $39 \mathrm{I} 91$ erg $=1.93045 \mathrm{E}-02 \quad 2.18749 \mathrm{E}-02$ method=2

pert711:n cell=1 mat=2 rho=9.598577845E-02 rxn=51 39I 91 erg $=2.18749 \mathrm{E}-02 \quad 2.48000 \mathrm{E}-02$ method $=2$

pert712: $\mathrm{n}$ cell=1 mat=2 rho=9.598577845E-02 rxn=51 39I 91 erg $=2.48000 \mathrm{E}-02 \quad 2.80879 \mathrm{E}-02$ method=2

pert713:n cell=1 mat=2 rho=9.598577845E-02 rxn=51 $39 I 91$ erg $=2.80879 \mathrm{E}-02 \quad 3.18278 \mathrm{E}-02$ method $=2$

pert714:n cell=1 mat=2 rho=9.598577845E-02 rxn=51 39I 91 erg $=3.18278 \mathrm{E}-02 \quad 3.60656 \mathrm{E}-02$ method $=2$

pert715: $\mathrm{n}$ cell=1 mat=2 rho=9.598577845E-02 rxn=51 39I 91 erg $=3.60656 \mathrm{E}-02 \quad 4.08677 \mathrm{E}-02$ method $=2$

pert716:n cell=1 mat=2 rho=9.598577845E-02 rxn=51 39I 91 erg $=4.08677 \mathrm{E}-02 \quad 4.63092 \mathrm{E}-02$ method $=2$

pert717:n cell=1 mat=2 rho=9.598577845E-02 rxn=51 39I 91 erg $=4.63092 \mathrm{E}-02 \quad 5.24752 \mathrm{E}-02$ method $=2$

pert718: $\mathrm{n}$ cell=1 mat=2 rho=9.598577845E-02 rxn=51 39I 91 erg $=5.24752 \mathrm{E}-025.94622 \mathrm{E}-02$ method=2

pert719: $\mathrm{n}$ cell=1 mat=2 rho=9.598577845E-02 rxn=51 $39 \mathrm{I} 91$ erg $=5.94622 \mathrm{E}-026.76000 \mathrm{E}-02$ method=2

pert720:n cell=1 mat=2 rho=9.598577845E-02 rxn=51 39I 91 erg $=6.76000 \mathrm{E}-027.63509 \mathrm{E}-02$ method $=2$

pert721:n cell=1 mat=2 rho=9.598577845E-02 rxn=51 39I 91 erg $=7.63509 \mathrm{E}-02 \quad 8.65170 \mathrm{E}-02$ method $=2$

pert722: $\mathrm{n}$ cell=1 mat=2 rho=9.598577845E-02 rxn=51 39I 91 erg $=8.65170 \mathrm{E}-02 \quad 9.80366 \mathrm{E}-02$ method $=2$

pert723:n cell=1 mat=2 rho=9.598577845E-02 rxn=51 39I 91 erg $=9.80366 \mathrm{E}-021.11090 \mathrm{E}-01$ method $=2$

pert724:n cell=1 mat=2 rho=9.598577845E-02 rxn=51 39I 91 erg=1.11090E-01 1.25881E-01 method=2

pert725: $\mathrm{n}$ cell=1 mat=2 rho=9.598577845E-02 rxn=51 39I 91 erg $=1.25881 \mathrm{E}-01 \quad 1.42642 \mathrm{E}-01$ method=2 
pert726: $\mathrm{n}$ cell=1 mat=2 rho=9.598577845E-02 rxn=51 39I 91 erg $=1.42642 \mathrm{E}-01 \quad 1.61635 \mathrm{E}-01$ method $=2$

pert727:n cell=1 mat=2 rho=9.598577845E-02 rxn=51 39I 91 erg $=1.61635 \mathrm{E}-01 \quad 1.84000 \mathrm{E}-01$ method $=2$

pert728:n cell=1 mat=2 rho=9.598577845E-02 rxn=51 39I 91 erg $=1.84000 \mathrm{E}-01 \quad 1.94969 \mathrm{E}-01$ method $=2$

pert729:n cell=1 mat=2 rho=9.598577845E-02 rxn=51 39I 91 erg $=1.94969 \mathrm{E}-01 \quad 2.07543 \mathrm{E}-01$ method $=2$

pert730:n cell=1 mat=2 rho=9.598577845E-02 rxn=51 39I 91 erg $=2.07543 \mathrm{E}-012.20929 \mathrm{E}-01$ method $=2$

pert731: $\mathrm{n}$ cell=1 mat=2 rho=9.598577845E-02 rxn=51 39I 91 erg $=2.20929 \mathrm{E}-012.35177 \mathrm{E}-01$ method=2

pert732: $\mathrm{n}$ cell=1 mat=2 rho=9.598577845E-02 rxn=51 39I 91 erg $=2.35177 \mathrm{E}-012.50345 \mathrm{E}-01$ method=2

pert733: $\mathrm{n}$ cell=1 mat=2 rho=9.598577845E-02 rxn=51 39I 91 erg $=2.50345 \mathrm{E}-01 \quad 2.66491 \mathrm{E}-01$ method $=2$

pert734:n cell=1 mat=2 rho=9.598577845E-02 rxn=51 39I 91 erg $=2.66491 \mathrm{E}-012.83678 \mathrm{E}-01$ method $=2$

pert735: $\mathrm{n}$ cell=1 mat=2 rho=9.598577845E-02 rxn=51 $39 \mathrm{I} 91$ erg $=2.83678 \mathrm{E}-013.03000 \mathrm{E}-01$ method $=2$

pert736: $\mathrm{n}$ cell=1 mat=2 rho=9.598577845E-02 rxn=51 $39 \mathrm{I} 91$ erg $=3.03000 \mathrm{E}-013.21449 \mathrm{E}-01$ method $=2$

pert737:n cell=1 mat=2 rho=9.598577845E-02 rxn=51 39191 erg=3.21449E-01 3.42181E-01 method=2

pert738:n cell=1 mat=2 rho=9.598577845E-02 rxn=51 39I 91 erg $=3.42181 \mathrm{E}-01 \quad 3.64250 \mathrm{E}-01$ method $=2$

pert739:n cell=1 mat=2 rho=9.598577845E-02 rxn=51 39I 91 erg $=3.64250 \mathrm{E}-01 \quad 3.87742 \mathrm{E}-01$ method $=2$

pert740:n cell=1 mat=2 rho=9.598577845E-02 rxn=51 39I 91 erg $=3.87742 \mathrm{E}-01 \quad 4.12749 \mathrm{E}-01$ method $=2$

pert741: $\mathrm{n}$ cell=1 mat=2 rho=9.598577845E-02 rxn=51 39I 91 erg $=4.12749 \mathrm{E}-01 \quad 4.39369 \mathrm{E}-01$ method=2

pert742: $\mathrm{n}$ cell=1 mat=2 rho=9.598577845E-02 rxn=51 39I 91 erg $=4.39369 \mathrm{E}-01 \quad 4.67706 \mathrm{E}-01$ method=2

pert743:n cell=1 mat=2 rho=9.598577845E-02 rxn=51 39I 91 erg $=4.67706 \mathrm{E}-015.00000 \mathrm{E}-01$ method $=2$

pert744:n cell=1 mat=2 rho=9.598577845E-02 rxn=51 39I 91 erg $=5.00000 \mathrm{E}-015.29981 \mathrm{E}-01$ method $=2$

pert745:n cell=1 mat=2 rho=9.598577845E-02 rxn=51 39I 91 erg $=5.29981 \mathrm{E}-01 \quad 5.64161 \mathrm{E}-01$ method=2

pert746:n cell=1 mat=2 rho=9.598577845E-02 rxn=51 39I 91 erg $=5.64161 \mathrm{E}-01 \quad 6.00547 \mathrm{E}-01$ method=2

pert747:n cell=1 mat=2 rho=9.598577845E-02 rxn=51 39I 91 erg $=6.00547 \mathrm{E}-016.39279 \mathrm{E}-01$ method $=2$

pert748:n cell=1 mat=2 rho=9.598577845E-02 rxn=51 39I 91 erg $=6.39279 \mathrm{E}-01 \quad 6.80509 \mathrm{E}-01$ method $=2$

pert749:n cell=1 mat=2 rho=9.598577845E-02 rxn=51 39I 91 erg $=6.80509 \mathrm{E}-017.24398 \mathrm{E}-01$ method $=2$

pert750:n cell=1 mat=2 rho=9.598577845E-02 rxn=51 39I 91 erg $=7.24398 \mathrm{E}-017.71117 \mathrm{E}-01$ method $=2$

pert751:n cell=1 mat=2 rho=9.598577845E-02 rxn=51 39I 91 erg $=7.71117 \mathrm{E}-018.23000 \mathrm{E}-01$ method=2

pert752: $\mathrm{n}$ cell=1 mat=2 rho=9.598577845E-02 rxn=51 39I 91 erg $=8.23000 \mathrm{E}-018.73790 \mathrm{E}-01$ method $=2$

pert753:n cell=1 mat=2 rho=9.598577845E-02 rxn=51 39I 91 erg $=8.73790 \mathrm{E}-019.30145 \mathrm{E}-01$ method $=2$

pert754:n cell=1 mat=2 rho=9.598577845E-02 rxn=51 39I 91 erg $=9.30145 \mathrm{E}-019.90134 \mathrm{E}-01$ method $=2$

pert755:n cell=1 mat=2 rho=9.598577845E-02 rxn=51 39I 91 erg $=9.90134 \mathrm{E}-01 \quad 1.05399 \mathrm{E}+00$ method $=2$

pert756:n cell=1 mat=2 rho=9.598577845E-02 rxn=51 39191 erg $=1.05399 \mathrm{E}+001.12197 \mathrm{E}+00$ method $=2$

pert757:n cell=1 mat=2 rho=9.598577845E-02 rxn=51 39I 91 erg $=1.12197 \mathrm{E}+001.19433 \mathrm{E}+00$ method=2

pert758: $\mathrm{n}$ cell=1 mat=2 rho=9.598577845E-02 rxn=51 39I 91 erg $=1.19433 \mathrm{E}+001.27136 \mathrm{E}+00$ method $=2$

pert759:n cell=1 mat=2 rho=9.598577845E-02 rxn=51 39I 91 erg $=1.27136 \mathrm{E}+001.35300 \mathrm{E}+00$ method $=2$

pert760:n cell=1 mat=2 rho=9.598577845E-02 rxn=51 39I 91 erg $=1.35300 \mathrm{E}+001.39631 \mathrm{E}+00$ method $=2$

pert761:n cell=1 mat=2 rho=9.598577845E-02 rxn=51 39I 91 erg $=1.39631 \mathrm{E}+001.44064 \mathrm{E}+00$ method $=2$

pert762: $\mathrm{n}$ cell=1 mat=2 rho=9.598577845E-02 rxn=51 39I 91 erg $=1.44064 \mathrm{E}+001.48637 \mathrm{E}+00$ method=2 
pert763: $\mathrm{n}$ cell=1 mat=2 rho=9.598577845E-02 rxn=51 39I 91 erg $=1.48637 \mathrm{E}+001.53355 \mathrm{E}+00$ method $=2$

pert764:n cell=1 mat=2 rho=9.598577845E-02 rxn=51 39I 91 erg $=1.53355 \mathrm{E}+001.58223 \mathrm{E}+00$ method $=2$

pert765: $\mathrm{n}$ cell=1 mat=2 rho=9.598577845E-02 rxn=51 39I 91 erg $=1.58223 \mathrm{E}+001.63246 \mathrm{E}+00$ method $=2$

pert766:n cell=1 mat=2 rho=9.598577845E-02 rxn=51 39I 91 erg $=1.63246 \mathrm{E}+001.68427 \mathrm{E}+00$ method $=2$

pert767:n cell=1 mat=2 rho=9.598577845E-02 rxn=51 39I 91 erg $=1.68427 \mathrm{E}+001.73800 \mathrm{E}+00$ method $=2$

pert768:n cell=1 mat=2 rho=9.598577845E-02 rxn=51 39I 91 erg $=1.73800 \mathrm{E}+001.79290 \mathrm{E}+00$ method=2

pert769:n cell=1 mat=2 rho=9.598577845E-02 rxn=51 39I 91 erg=1.79290E+00 1.84981E+00 method=2

pert770:n cell=1 mat=2 rho=9.598577845E-02 rxn=51 39I 91 erg $=1.84981 \mathrm{E}+001.90853 \mathrm{E}+00$ method $=2$

pert771:n cell=1 mat=2 rho=9.598577845E-02 rxn=51 39I 91 erg $=1.90853 \mathrm{E}+001.96912 \mathrm{E}+00$ method $=2$

pert772: $\mathrm{n}$ cell=1 mat=2 rho=9.598577845E-02 rxn=51 $39 \mathrm{I} 91$ erg $=1.96912 \mathrm{E}+002.03162 \mathrm{E}+00$ method $=2$

pert773: $\mathrm{n}$ cell=1 mat=2 rho=9.598577845E-02 rxn=51 $39 \mathrm{I} 91$ erg $=2.03162 \mathrm{E}+002.09611 \mathrm{E}+00$ method $=2$

pert774: $\mathrm{n}$ cell=1 mat=2 rho=9.598577845E-02 rxn=51 $39 \mathrm{I} 91$ erg $=2.09611 \mathrm{E}+002.16265 \mathrm{E}+00$ method $=2$

pert775: $\mathrm{n}$ cell=1 mat=2 rho=9.598577845E-02 rxn=51 39I 91 erg $=2.16265 \mathrm{E}+002.23200 \mathrm{E}+00$ method $=2$

pert776:n cell=1 mat=2 rho=9.598577845E-02 rxn=51 39I 91 erg $=2.23200 \mathrm{E}+002.30213 \mathrm{E}+00$ method $=2$

pert777:n cell=1 mat=2 rho=9.598577845E-02 rxn=51 39I 91 erg $=2.30213 \mathrm{E}+00 \quad 2.37521 \mathrm{E}+00$ method $=2$

pert778: $\mathrm{n}$ cell=1 mat=2 rho=9.598577845E-02 rxn=51 39I 91 erg $=2.37521 \mathrm{E}+002.45061 \mathrm{E}+00$ method $=2$

pert779: $\mathrm{n}$ cell=1 mat=2 rho=9.598577845E-02 rxn=51 39I 91 erg $=2.45061 \mathrm{E}+002.52840 \mathrm{E}+00$ method=2

pert780:n cell=1 mat=2 rho=9.598577845E-02 rxn=51 39I 91 erg $=2.52840 \mathrm{E}+002.60866 \mathrm{E}+00$ method $=2$

pert781:n cell=1 mat=2 rho=9.598577845E-02 rxn=51 39I 91 erg $=2.60866 \mathrm{E}+002.69146 \mathrm{E}+00$ method $=2$

pert782: $\mathrm{n}$ cell=1 mat=2 rho=9.598577845E-02 rxn=51 39I 91 erg $=2.69146 \mathrm{E}+002.77690 \mathrm{E}+00$ method $=2$

pert783:n cell=1 mat=2 rho=9.598577845E-02 rxn=51 39I 91 erg $=2.77690 \mathrm{E}+002.86500 \mathrm{E}+00$ method $=2$

pert784:n cell=1 mat=2 rho=9.598577845E-02 rxn=51 $39 \mathrm{I} 91$ erg $=2.86500 \mathrm{E}+002.95599 \mathrm{E}+00$ method $=2$

pert785:n cell=1 mat=2 rho=9.598577845E-02 rxn=51 39I 91 erg $=2.95599 \mathrm{E}+003.04983 \mathrm{E}+00$ method $=2$

pert786: $\mathrm{n}$ cell=1 mat=2 rho=9.598577845E-02 rxn=51 39I 91 erg $=3.04983 \mathrm{E}+003.14664 \mathrm{E}+00$ method $=2$

pert787: $\mathrm{n}$ cell=1 mat=2 rho=9.598577845E-02 rxn=51 39I 91 erg $=3.14664 \mathrm{E}+00 \quad 3.24652 \mathrm{E}+00$ method $=2$

pert788:n cell=1 mat=2 rho=9.598577845E-02 rxn=51 39I 91 erg $=3.24652 \mathrm{E}+00 \quad 3.34958 \mathrm{E}+00$ method $=2$

pert789: $\mathrm{n}$ cell=1 mat=2 rho=9.598577845E-02 rxn=51 39I 91 erg $=3.34958 \mathrm{E}+00 \quad 3.45591 \mathrm{E}+00$ method=2

pert790:n cell=1 mat=2 rho=9.598577845E-02 rxn=51 39I 91 erg $=3.45591 \mathrm{E}+00 \quad 3.56561 \mathrm{E}+00$ method $=2$

pert791:n cell=1 mat=2 rho=9.598577845E-02 rxn=51 39I 91 erg $=3.56561 \mathrm{E}+003.68000 \mathrm{E}+00$ method $=2$

pert792: $\mathrm{n}$ cell=1 mat=2 rho=9.598577845E-02 rxn=51 39I 91 erg $=3.68000 \mathrm{E}+003.79557 \mathrm{E}+00$ method $=2$

pert793:n cell=1 mat=2 rho=9.598577845E-02 rxn=51 39I 91 erg $=3.79557 \mathrm{E}+003.91606 \mathrm{E}+00$ method $=2$

pert794:n cell=1 mat=2 rho=9.598577845E-02 rxn=51 39I 91 erg $=3.91606 \mathrm{E}+004.04037 \mathrm{E}+00$ method $=2$

pert795: $\mathrm{n}$ cell=1 mat=2 rho=9.598577845E-02 rxn=51 39I 91 erg $=4.04037 \mathrm{E}+00 \quad 4.16862 \mathrm{E}+00$ method $=2$

pert796:n cell=1 mat=2 rho=9.598577845E-02 rxn=51 39I 91 erg $=4.16862 \mathrm{E}+00 \quad 4.30095 \mathrm{E}+00$ method $=2$

pert797:n cell=1 mat=2 rho=9.598577845E-02 rxn=51 39I 91 erg $=4.30095 \mathrm{E}+00 \quad 4.43747 \mathrm{E}+00$ method $=2$

pert798:n cell=1 mat=2 rho=9.598577845E-02 rxn=51 39I 91 erg $=4.43747 \mathrm{E}+00 \quad 4.57833 \mathrm{E}+00$ method $=2$

pert799: $\mathrm{n}$ cell=1 mat=2 rho=9.598577845E-02 rxn=51 39I 91 erg $=4.57833 \mathrm{E}+00 \quad 4.72367 \mathrm{E}+00$ method $=2$ 
pert800:n cell=1 mat=2 rho=9.598577845E-02 rxn=51 39I 91 erg $=4.72367 \mathrm{E}+00 \quad 4.87361 \mathrm{E}+00$ method $=2$

pert801:n cell=1 mat=2 rho=9.598577845E-02 rxn=51 39I 91 erg $=4.87361 \mathrm{E}+00 \quad 5.02832 \mathrm{E}+00$ method $=2$

pert802:n cell=1 mat=2 rho=9.598577845E-02 rxn=51 39I 91 erg $=5.02832 \mathrm{E}+00 \quad 5.18793 \mathrm{E}+00$ method $=2$

pert803:n cell=1 mat=2 rho=9.598577845E-02 rxn=51 39I 91 erg $=5.18793 \mathrm{E}+00 \quad 5.35261 \mathrm{E}+00$ method $=2$

pert804:n cell=1 mat=2 rho=9.598577845E-02 rxn=51 39I 91 erg $=5.35261 \mathrm{E}+00 \quad 5.52252 \mathrm{E}+00$ method $=2$

pert805:n cell=1 mat=2 rho=9.598577845E-02 rxn=51 39I 91 erg $=5.52252 \mathrm{E}+00 \quad 5.69783 \mathrm{E}+00$ method $=2$

pert806:n cell=1 mat=2 rho=9.598577845E-02 rxn=51 39I 91 erg $=5.69783 \mathrm{E}+005.87870 \mathrm{E}+00$ method $=2$

pert807:n cell=1 mat=2 rho=9.598577845E-02 rxn=51 39I 91 erg $=5.87870 \mathrm{E}+006.07000 \mathrm{E}+00$ method $=2$

pert808:n cell=1 mat=2 rho=9.598577845E-02 rxn=51 39I 91 erg $=6.07000 \mathrm{E}+006.25784 \mathrm{E}+00$ method $=2$

pert809: $\mathrm{n}$ cell=1 mat=2 rho=9.598577845E-02 rxn=51 $39 \mathrm{I} 91$ erg $=6.25784 \mathrm{E}+006.45649 \mathrm{E}+00$ method $=2$

pert810:n cell=1 mat=2 rho=9.598577845E-02 rxn=51 39191 erg $=6.45649 \mathrm{E}+006.66144 \mathrm{E}+00$ method $=2$

pert811: $\mathrm{n}$ cell=1 mat=2 rho=9.598577845E-02 rxn=51 $39 \mathrm{I} 91$ erg $=6.66144 \mathrm{E}+006.87289 \mathrm{E}+00$ method $=2$

pert812:n cell=1 mat=2 rho=9.598577845E-02 rxn=51 39191 erg $=6.87289 \mathrm{E}+007.09106 \mathrm{E}+00$ method $=2$

pert813: $\mathrm{n}$ cell=1 mat=2 rho=9.598577845E-02 rxn=51 39I 91 erg $=7.09106 \mathrm{E}+007.31616 \mathrm{E}+00$ method $=2$

pert814: $\mathrm{n}$ cell=1 mat=2 rho=9.598577845E-02 rxn=51 39I 91 erg $=7.31616 \mathrm{E}+007.54840 \mathrm{E}+00$ method $=2$

pert815:n cell=1 mat=2 rho=9.598577845E-02 rxn=51 39I 91 erg $=7.54840 \mathrm{E}+007.79000 \mathrm{E}+00$ method $=2$

pert816:n cell=1 mat=2 rho=9.598577845E-02 rxn=51 39I 91 erg $=7.79000 \mathrm{E}+008.03523 \mathrm{E}+00$ method $=2$

pert817:n cell=1 mat=2 rho=9.598577845E-02 rxn=51 39I 91 erg $=8.03523 \mathrm{E}+008.29029 \mathrm{E}+00$ method $=2$

pert818: $\mathrm{n}$ cell=1 mat=2 rho=9.598577845E-02 rxn=51 39I 91 erg $=8.29029 \mathrm{E}+008.55345 \mathrm{E}+00$ method $=2$

pert819: $\mathrm{n}$ cell=1 mat=2 rho=9.598577845E-02 rxn=51 $39 \mathrm{I} 91$ erg $=8.55345 \mathrm{E}+00 \quad 8.82497 \mathrm{E}+00$ method $=2$

pert $820: \mathrm{n}$ cell=1 mat=2 rho=9.598577845E-02 rxn=51 39I 91 erg $=8.82497 \mathrm{E}+00$ 9.10510 $\mathrm{E}+00$ method $=2$

pert821:n cell=1 mat=2 rho=9.598577845E-02 rxn=51 39191 erg $=9.10510 \mathrm{E}+00$ 9.39413E+00 method $=2$

pert822: n cell=1 mat=2 rho=9.598577845E-02 rxn=51 39I 91 erg $=9.39413 \mathrm{E}+00 \quad 9.69233 \mathrm{E}+00$ method $=2$

pert823: $\mathrm{n}$ cell=1 mat=2 rho=9.598577845E-02 rxn=51 39I 91 erg $=9.69233 \mathrm{E}+001.00000 \mathrm{E}+01$ method $=2$

pert $824: \mathrm{n}$ cell=1 mat=2 rho=9.598577845E-02 rxn=51 $39 \mathrm{I} 91$ erg $=1.00000 \mathrm{E}+011.02500 \mathrm{E}+01$ method $=2$

pert825:n cell=1 mat=2 rho=9.598577845E-02 rxn=51 39I 91 erg $=1.02500 \mathrm{E}+01 \quad 1.05000 \mathrm{E}+01$ method $=2$

pert826:n cell=1 mat=2 rho=9.598577845E-02 rxn=51 39I 91 erg=1.05000E+01 1.07500E+01 method=2

pert827:n cell=1 mat=2 rho=9.598577845E-02 rxn=51 39I 91 erg $=1.07500 \mathrm{E}+011.10000 \mathrm{E}+01$ method $=2$

pert828:n cell=1 mat=2 rho=9.598577845E-02 rxn=51 39I 91 erg $=1.10000 \mathrm{E}+01$ 1.12500E+01 method $=2$

pert829:n cell=1 mat=2 rho=9.598577845E-02 rxn=51 39I 91 erg $=1.12500 \mathrm{E}+01 \quad 1.15000 \mathrm{E}+01$ method=2

pert $830: \mathrm{n}$ cell=1 mat=2 rho=9.598577845E-02 rxn=51 $39 \mathrm{I} 91$ erg $=1.15000 \mathrm{E}+01$ 1.17500E+01 method $=2$

pert831: $\mathrm{n}$ cell=1 mat=2 rho=9.598577845E-02 rxn=51 39I 91 erg $=1.17500 \mathrm{E}+01$ 1.20000E+01 method=2

pert832: $\mathrm{n}$ cell=1 mat=2 rho=9.598577845E-02 rxn=51 39I 91 erg=1.20000E+01 1.22500E+01 method=2

pert833: $\mathrm{n}$ cell=1 mat=2 rho=9.598577845E-02 rxn=51 39I 91 erg $=1.22500 \mathrm{E}+01 \quad 1.25000 \mathrm{E}+01$ method $=2$

pert834:n cell=1 mat=2 rho=9.598577845E-02 rxn=51 39I 91 erg $=1.25000 \mathrm{E}+01$ 1.27500E+01 method $=2$

pert835: $\mathrm{n}$ cell=1 mat=2 rho=9.598577845E-02 rxn=51 39I 91 erg $=1.27500 \mathrm{E}+01 \quad 1.30000 \mathrm{E}+01$ method $=2$

pert836:n cell=1 mat=2 rho=9.598577845E-02 rxn=51 39I 91 erg $=1.30000 \mathrm{E}+01$ 1.32500E+01 method=2 
pert837:n cell=1 mat=2 rho=9.598577845E-02 rxn=51 39I 91 erg $=1.32500 \mathrm{E}+01$ 1.35000E+01 method $=2$

pert838:n cell=1 mat=2 rho=9.598577845E-02 rxn=51 39I 91 erg $=1.35000 \mathrm{E}+01$ 1.37500E +01 method $=2$

pert839:n cell=1 mat=2 rho=9.598577845E-02 rxn=51 39I 91 erg $=1.37500 \mathrm{E}+01$ 1.40000E+01 method $=2$

pert $840: \mathrm{n}$ cell=1 mat=2 rho=9.598577845E-02 rxn=51 39I 91 erg $=1.40000 \mathrm{E}+01$ 1.42500E+01 method $=2$

pert841:n cell=1 mat=2 rho=9.598577845E-02 rxn=51 39I 91 erg $=1.42500 \mathrm{E}+01$ 1.45000E+01 method=2

pert842: $\mathrm{n}$ cell=1 mat=2 rho=9.598577845E-02 rxn=51 39I 91 erg=1.45000E+01 1.47500E+01 method=2

pert $843: \mathrm{n}$ cell=1 mat=2 rho=9.598577845E-02 rxn=51 39I 91 erg $=1.47500 \mathrm{E}+01$ 1.50000E+01 method=2

pert $844: \mathrm{n}$ cell=1 mat=2 rho=9.598577845E-02 rxn=51 39I 91 erg $=1.50000 \mathrm{E}+01$ 1.52500E+01 method $=2$

pert $845: \mathrm{n}$ cell=1 mat=2 rho=9.598577845E-02 rxn=51 39I 91 erg $=1.52500 \mathrm{E}+01$ 1.55000E+01 method=2

pert846:n cell=1 mat=2 rho=9.598577845E-02 rxn=51 39I 91 erg $=1.55000 \mathrm{E}+011.57500 \mathrm{E}+01$ method $=2$

pert847:n cell=1 mat=2 rho=9.598577845E-02 rxn=51 39I 91 erg $=1.57500 \mathrm{E}+011.60000 \mathrm{E}+01$ method $=2$

pert848:n cell=1 mat=2 rho=9.598577845E-02 rxn=51 39I 91 erg $=1.60000 \mathrm{E}+011.62500 \mathrm{E}+01$ method $=2$

pert849:n cell=1 mat=2 rho=9.598577845E-02 rxn=51 39I 91 erg $=1.62500 \mathrm{E}+01 \quad 1.65000 \mathrm{E}+01$ method $=2$

pert850:n cell=1 mat=2 rho=9.598577845E-02 rxn=51 39191 erg $=1.65000 \mathrm{E}+011.67500 \mathrm{E}+01$ method $=2$

pert851:n cell=1 mat=2 rho=9.598577845E-02 rxn=51 39I 91

nps $\quad 6$ e 8 erg $=1.67500 \mathrm{E}+011.70000 \mathrm{E}+01$ method=2

prdmp j $6 e 7$

print 